\title{
Assessing the Vulnerability of Agriculture Systems to Climate Change in Coastal Areas: A Novel Index
}

\author{
Komali Kantamaneni ${ }^{1, *}$, Louis Rice $^{2}$, Komali Yenneti ${ }^{3,4}$ and Luiza C. Campos ${ }^{5}$ \\ 1 Warsash School of Maritime Science and Engineering, Solent University, East Park Terrace, \\ Southampton SO14 OYN, UK \\ 2 Centre for Architecture and Built Environment Research, University of the West of England, \\ Bristol BS16 1QY, UK; Louis.Rice@uwe.ac.uk \\ 3 Australia India Institute, University of Melbourne, 149 Barry Street, Parkville, VIC 3053, Australia; \\ kyenneti@unimelb.edu.au \\ 4 School of Architecture and Built Environment, Faculty of Science and Engineering, University of \\ Wolverhampton, Wulfruna St, Wolverhampton WV1 1LY, UK \\ 5 Department of Civil, Environment \& Geomatic Engineering, University College London (UCL), \\ Gower Street, London WC1E 6BT, UK; l.campos@ucl.ac.uk \\ * Correspondence: komali.kantamaneni@solent.ac.uk
}

Received: 25 March 2020; Accepted: 9 June 2020; Published: 11 June 2020

\begin{abstract}
This study proposes a novel index to evaluate agricultural vulnerability to climate change in coastal areas, using the case of Andhra Pradesh, the state with the second longest coastline in India. Field data was collected from more than 1000 farmers (involved in over 50 varieties of crops) in 22 riverine and coastal case study areas. Data was collected through site visits, surveys and five workshops conducted between November 2018 and June 2019. Based on the collected data sets, a new Agricultural Coastal Vulnerability Index (AGCVI) was developed and applied to the 22 sites located in two districts (Krishna and Guntur) of Coastal Andhra Pradesh. The analysis revealed that the areas with three crop seasons (Kharif, Rabi and Zaid) per year are highly vulnerable to climate change. On the other hand, sites with one crop season (Kharif) per annum are the least vulnerable to climate change. Moreover, grains (particularly rice), flowers and fruit crops are more susceptible to climate change and its induced impacts. Rice is no longer a profitable crop in the case study areas partly as a result of unfavourable weather conditions, inadequate insurance provision and lack of government support for farmers. Cumulatively, all these circumstances impact farmers' incomes and socio-cultural practices: this is leading to a marriage crisis, with a reduction in the desirability of matrimony to farmers. These findings provide valuable information that can support climate and agriculture policies, as well as sustainable cropping patterns among farmers' communities in coastal areas of India in the future.
\end{abstract}

Keywords: agriculture; coastal areas; new index; vulnerability; farmers; crops; Coastal Andhra Pradesh

\section{Introduction}

Agriculture contributes to economic development via fiscal activities, as a supplier of food and rural services, and as a distinctive mechanism for growth. In low and middle income countries, nearly 3 billion people live in rural areas and of those, 2.5 billion people depend on agriculture for livelihood [1]. Currently, 1.5 billion hectares (11 percent) of the global land surface is under agriculture, and this is predicted to increase over the next thirty years [2]. The largest farmlands are located in Asia, which represent 33.8 percent of the global value [3]. 
Global warming is a serious threat to agriculture and crop yield. There has been growing concern regarding the effects of climate change on crop productivity, food security and hydrological imbalances [4-6]. According to the United Nations [7], the current amount of warming can decrease grain production up to 70 percent in low and middle income countries. In South Asia and Africa, the overall mean yield of all crops will suffer an eight percent decrease by 2050, particularly affecting wheat, maize and sorghum grain production [8].

Multifaceted climate change impacts on agriculture vary in different parts of the world and the overall picture is very complex in coastal areas. The global coastal zones comprise only two percent of the earth's surface, but contain over 10 percent of the total population (600 million people), and the density of coastal populations is higher than in non-coastal regions [9]. To cater for the needs of this population, many of the coastal environments across the world have been altered for agricultural purposes [10]. Therefore, low-lying agricultural land is highly vulnerable to severe soil salinity, storm surge, coastal erosion and stagnant flood water problems [11-14]. Simultaneously, the rapid and overwhelming changes to the climatic environment and associated factors have intensified the vulnerability of agricultural production in coastal areas [15-18].

Agriculture in India faces even more complex challenges, due to diverse factors such as the shrinking amount of agricultural land, depletion of water and irrigation sources and increased labour costs [19]. As about 60 percent of the cultivated area is rain-fed [20], climate change would not only affect the overall production of food crops and the food security of millions of people, but also threaten their livelihoods. A study reveals that variations in climate change and other climate induced factors, particularly monsoons, led to a four percent reduction in rice yield in India between 1966 and 2002 [21]. Further, according to Cline [22], global warming is expected to reduce crop production in India between $10-40$ percent by the end of the 21 st century.

India has $7516.6 \mathrm{~km}$ of coastline [23] and contains several river deltas along the coastal stretches, which are very fertile and favourable for farming and cultivation of a wide variety of crops. However, it is predicted that climate change will affect crop yields in these areas through impact on agricultural inputs (e.g., water for irrigation), growth of plants (due to increased temperatures) and limiting the types of crops that can be grown in certain areas (e.g., coastal areas). Farmers depending on rainfall will be particularly susceptible to the impacts of climate change and severely affected if they don't adjust to the climate variabilities [24]. The abovementioned issues reveal the interconnection between the impacts of climate change, agriculture and the susceptibility of people depending on agriculture in India's coastal areas.

The main objective of this research is to assess and interpret the vulnerability of agriculture in rural coastal areas in India. We attempt to: (a) develop a new composite index to measure the vulnerability of agriculture in coastal areas; (b) develop a sub-regional level agricultural vulnerability profile from the perspectives of both crop productivity and farmers lives; and (c) provide some interpretation of the applicability of the developed index. The spatial scale of this study is 22 selected case study sites in two districts of Coastal Andhra Pradesh (CAP), India. The vast coastline, heterogeneity in agriculture patterns and socio-economic conditions, and the increase in climatic variability makes it an excellent case study. This study takes forward the literature on coastal agricultural vulnerability by operationalising this framework in one of the world's largest agriculture-based economies [13,25]. The research results will be helpful to farmers and decision makers involved in the improvement of coastal agricultural policies.

\section{Theory and Analytical Framework}

\subsection{Literature Review}

Vulnerability to climate change, influenced by disasters [26,27], natural hazards [28,29] and food insecurity $[30,31]$ research, has drawn serious attention from researchers and policy-makers alike in the past two decades, leading to a large literature on the topic [32]. According to this literature, 
vulnerability conveys the degree of susceptibility of a natural ecosystem or socio-economic system to the impacts of climate change [33].

Agricultural vulnerability is generally defined as the latent probability of loss and damage of an agricultural system associated with climatic variabilities and the occurrence of an extreme climatic event, and the susceptibility of any individual or social group to its impacts [34,35]. The concept of agricultural vulnerability, therefore, focuses on the level of physiological impact on crops triggered by variabilities in various climatic elements and the socio-economic impacts on farmers [36,37].

Over recent years a large body of literature has emerged on the analysis of agricultural vulnerability [37-39]. According to this literature, climate change could affect agriculture systems in three interconnected ways: first, changes in temperature and rainfall pattern may alter the spatial distribution of agro-ecological zones and upset the timing and duration of crop growing seasons. These effects are strongest for crops such as wheat and rice. Second, variabilities in rainfall patterns impact water availability during crop growing season, and thereby decrease agricultural productivity. Finally, agricultural losses, due to the increased frequency of extreme climatic events, can affect farming practices and livelihoods. In general, agricultural vulnerability provides a useful theoretical framework, as it evaluates the possible susceptibility of crop yields, and assists in the appraisal of the trade-offs between climate-induced vulnerability of crop yields and farmer livelihoods [40,41]. Such an analysis aids the development of relevant adaptation strategies [42].

Different scholars identified a multitude of factors that influence agricultural vulnerability. In general, agricultural vulnerability is a variable condition generated by multiple environmental and social processes, and would depend and differ on diverse contexts and circumstances [41]. A large body of literature is, however, based on climatic parameters (e.g., temperature, rainfall, precipitation), crops and agriculture production [43-46], while a smaller body of scholarship is based on other socio-economic factors, such as economic development, agricultural production, human culture [47], budget and investments [43], national and local economies, market prices, farmers welfare [48], cultural settings: cumulatively all these elements affect the agricultural vulnerability, particularly in developing countries [38,49].

Reflecting on the above discussion, it is clear that there is a large body of literature on agricultural vulnerability and adaptation both in India and other countries. This study aims to fill these three key research gaps in the current research. First, while a considerable amount of literature on agricultural vulnerability [49-51] and coastal vulnerability [52-54], emerged over the years, there is relatively little work on the coastal agricultural vulnerability, particularly in India [55]. The majority of the existing studies on coastal agricultural vulnerability focus on other parts of the world $[13,25,56]$. Further, the limited existing work on coastal agricultural vulnerability both in India $[14,15]$ and globally $[18,25]$ seldom uses primary data and a combination of qualitative, quantitative and spatial methods. Second, much of the existing literature on both agricultural vulnerability $[36,41,42]$ and coastal vulnerability $[52,57]$ tend to neglect to analyse a combination of climatic and social perspectives. More specifically, there is a lacuna for in-depth and rigorous studies on assessment based on a combination of factors, such as weather information, size of the farm, leased land, cropping varieties, farming income and impacts on personal lives. Finally, most of the existing studies on agricultural vulnerability assessment in India have relied on the predicted impacts of climate change in the study region $[55,58]$. There is a scarcity of literature that utilises real and historical climatic (rainfall and temperature patterns) and disasters data at regional and/or local levels.

Building on Smit et al. [59], in this study, coastal agricultural vulnerability to climate change is defined as the degree to which an agricultural system (i.e., food crops directly and farmers indirectly) is susceptible, or unable to cope with adverse effects of climate change in coastal areas, in this milieu, from extreme temperatures, erosion, cyclones, flooding, storm surge and other climate extremes. 


\subsection{Conceptual Framework}

The diverse variety of indicator approaches developed across the world over the years indicate that there is no fixed method to measure agriculture vulnerability in coastal areas to climate variability (Table 1). Even a cursory review of these existing work show that, while there is an extensive body of literature on either coastal vulnerability or agriculture vulnerability, little literature focuses on the synthesis of both of them and, to the best of our knowledge, none at the sub-region level in India. Each method was developed in the context of specific research and geographic areas. Furthermore, most of the little existing global studies on coastal agricultural vulnerability are overly or exclusively quantitative or descriptive, while others are too complicated to adapt to different sub-regional geographical regions.

Table 1. An overview of global Coastal Vulnerability Index (CVI) assessments to different factors (chronological order).

\begin{tabular}{|c|c|c|}
\hline Reference & CVI- Vulnerability Method & Geographical Area \\
\hline Gornitz and Kanciruk (1989) & $\begin{array}{l}\text { Developed the first coastal hazard } \\
\text { database/vulnerability index }\end{array}$ & Global \\
\hline $\begin{array}{l}\text { Hareau, A., Hofstadter, R. \& } \\
\text { Saizar, A. (1999) }\end{array}$ & $\begin{array}{l}\text { Vulnerability to climate change. Considered coastal } \\
\text { resources as well }\end{array}$ & Uruguay \\
\hline Cutter et al. (2003) & Social vulnerability index & USA \\
\hline Kaly and Commission (1999) & Environmental vulnerability index & Global \\
\hline Pethick and Crooks 2000; & CVI- Geographical perspective & Conceptual paper \\
\hline Nelson et al. (2005) & CVI for broad acre agriculture & Australia \\
\hline Gbetibouo and Ringler (2009) & Mapped the farmers vulnerability to climate change & Africa \\
\hline McLaughlin and Cooper 2010 & Multi-scale CVI for assessing erosion impacts & UK \\
\hline Kumar and Kunte (2012) & CVI -South India & India \\
\hline Balica et al. (2012) & Flood vulnerability index & Global \\
\hline Wiréhn et al. (2015) & $\begin{array}{l}\text { Appraisal of composite index methods for } \\
\text { agricultural vulnerability }\end{array}$ & Sweden \\
\hline Huq et al. (2015) & $\begin{array}{l}\text { Assessed impacts of climate change and associate } \\
\text { factors on coastal agricultural communities }\end{array}$ & Bangladesh \\
\hline Shukla et al. (2016) & $\begin{array}{l}\text { Established Inherent vulnerability of agricultural } \\
\text { communities at village level }\end{array}$ & India \\
\hline Teshome (2016) & $\begin{array}{l}\text { Apprised farmers' agricultural land vulnerability to } \\
\text { climate change }\end{array}$ & Africa \\
\hline Panda (2017) & $\begin{array}{l}\text { Generated an index to evaluate farmers vulnerability } \\
\text { to drought }\end{array}$ & India \\
\hline Jose et al. (2017) & Established agricultural vulnerability index to floods & Philippines \\
\hline Kantamaneni et al. (2018) & Established combined coastal vulnerability index & UK \\
\hline Ng et al. (2019) & $\begin{array}{l}\text { Established CVI to evaluate small } \\
\text { islands vulnerability }\end{array}$ & Portugal \\
\hline Ducusin et al. (2019) & Assessed agricultural vulnerability to climate change & Philippines \\
\hline Sneessens et al. (2019) & $\begin{array}{l}\text { A framework has been established to measure the } \\
\text { fiscal vulnerability of farming systems }\end{array}$ & France \\
\hline Mahmood et al. (2020) & $\begin{array}{l}\text { Coastal vulnerability assessment of Meghna estuary } \\
\text { of Bangladesh }\end{array}$ & Bangladesh \\
\hline Sekovski et al. (2020) & Established CVI for Ravenna province & Italy \\
\hline Mohamed (2020) & Established CVI for Nile delta. & Egypt \\
\hline
\end{tabular}


Considering the differentiated vulnerability among the different states in India, we use the 'Agricultural Coastal Vulnerability Index' (AGCVI), developed for the purpose of our study (based on Kantamaneni et al. [60]). A new holistic and integrated indicator approach is needed to evaluate the agricultural vulnerability in CAP, because of its differentiated landscape, social, physical and economic geographic characteristics. Our approach is useful to evaluate the agriculture vulnerability in 22 case study sites of CAP because it uses different methods (quantitative, fieldwork and spatial analysis) and covers a full range of socioeconomic and cultural parameters in the current scenarios.

\section{Study Area}

\subsection{Case Study Sites}

The first step towards the development of a vulnerability index is to identify suitable case study sites. The case study area and sites are selected by using two-stage sampling technique. First, the study area, namely CAP, was selected purposively as it has the second largest coastline (more than $900 \mathrm{kms}$ ) in India (after Gujarat). Second, based on existing published work [53,61], recent events and multiple site visits, twenty-two suitable sites (Table 2) located in Krishna and Guntur districts of CAP (Figure 1) were selected for this study. While there are many agricultural vulnerability hotspots across the CAP, these selected case study locations are in need of immediate attention, and therefore those sites were selected for this study.

Table 2. Case study sites in Guntur and Krishna districts, Coastal Andhra Pradesh (CAP), India.

\begin{tabular}{cc}
\hline No. & Guntur District \\
\hline 1. & Nutakki \\
2. & Vadlapudi \\
3. & Pedapalem \\
4. & Nidamarru \\
5. & Aatmakuru \\
6. & Revendrapadu \\
7. & Namburu \\
8. & Kaza \\
9. & Kunchanapalli \\
10. & Vaddeswaram \\
11. & Kotha Palem \\
12. & Ippatam \\
13. & Nizampatnam \\
14. & Penumaka \\
15. & Paturu \\
16. & Tadepalli \\
17. & Bommivani palem \\
18. & Chirravuru \\
19. & Tulluru \\
20 & Mangalagiri \\
\hline & Krishna District \\
\hline 21. & Madalavarigudem \\
22. & Vijayawada rural \\
\hline
\end{tabular}




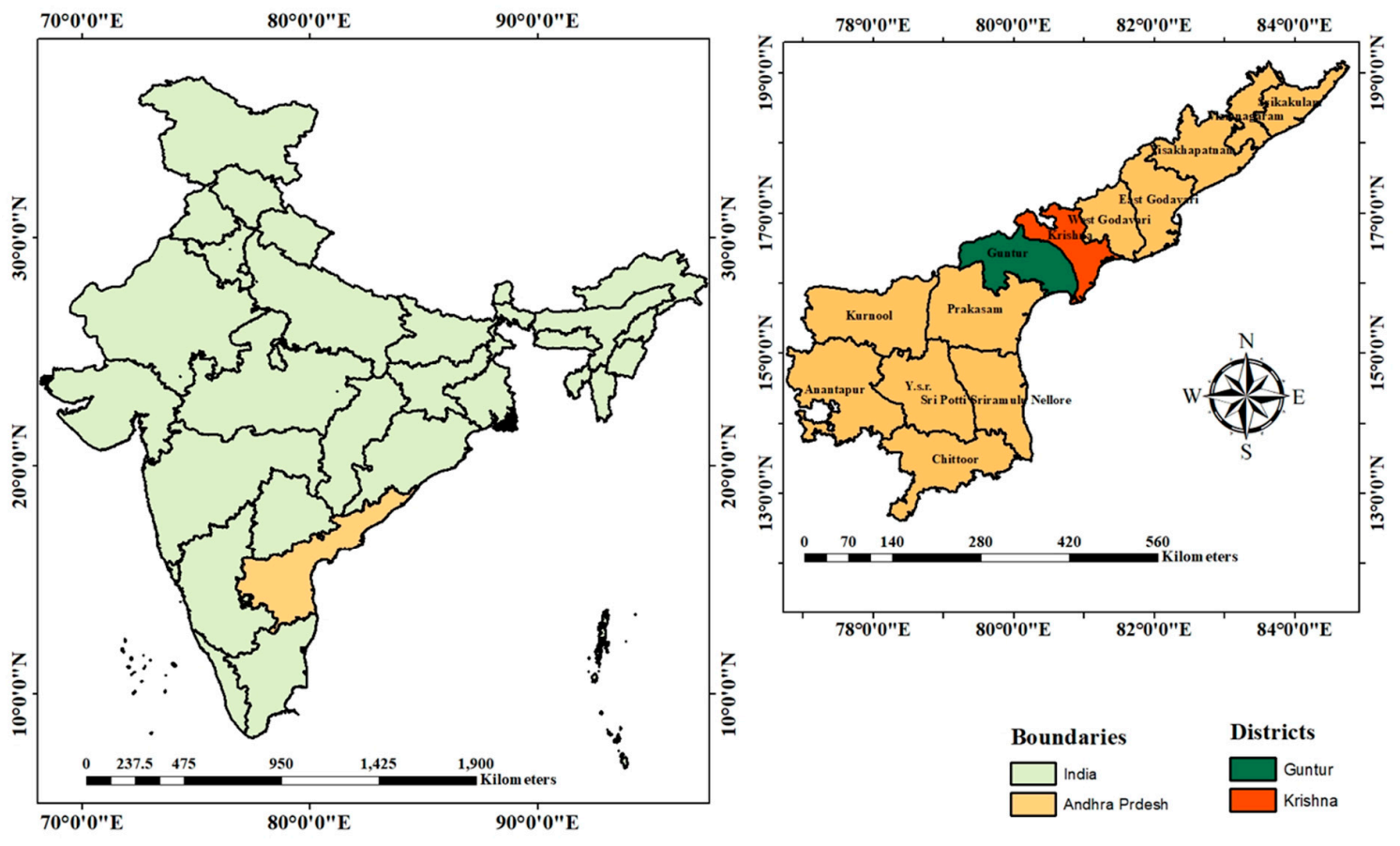

Figure 1. Study area with country and state boundaries.

\subsection{Physical Geography}

\subsubsection{Coastal Andhra Pradesh (CAP)}

CAP is located along the Eastern Indian coastline towards the Bay of Bengal, at a latitude $13^{\circ} 24^{\prime}$ $\mathrm{N}$ to $19^{\circ} 54^{\prime} \mathrm{N}$ and longitude $80^{\circ} 02^{\prime} \mathrm{E}$ to $86^{\circ} 46^{\prime} \mathrm{E}$. Krishna and Guntur districts are the part of CAP, with diverse physical, economic and geographical characteristics. The Krishna district is located in between $150-43^{\prime}$ and $170-10^{\prime}$ of the Northern latitude and 800 and $810-33^{\prime}$ of the Eastern longitude. The CAP region consists of $966 \mathrm{kms}$ of coastline, out of which the case study district has a total coastline of $188 \mathrm{kms}$ [62]. It is bounded by the Bay of Bengal and West Godavari district on the East, Bay of Bengal on the South, Guntur district on the West and Nalgonda districts and Khammam district on the North.

\subsubsection{Krishna District}

The Krishna district (Figure 1) has population of 4.5 million, and is divided into 50 mandals (equal to small group of village councils), six towns and 1005 villages [63]. The length of the River Krishna is $1280 \mathrm{kms}$, and it is a major river in this district [64]. Krishna river is the main source for irrigation, domestic and industrial use. The climate is moderate; considered tropical rainy, with extreme hot summers and annual rainfall of $1011.2 \mathrm{~mm}$. In Krishna district, 535,029 hectares were used for agriculture in 2004 [62]. The main crops are cereals, pulses, oilseeds and other crops. The Krishna district stands at fourth largest for population in the state and 60 percent of that population lives in rural areas; the population growth rate is 7.9 percent [63].

\subsubsection{Guntur District}

Guntur district (Figure 1) is located between North Latitudes $15^{\circ} 18^{\prime}$ and $16^{\circ} 50^{\prime}$, and East Longitude $79^{\circ} 10^{\prime}$ and $80^{\circ} 55^{\prime}$. The area is $11,328.23 \mathrm{~km}^{2}$, the population is 4.8 million and it is divided by 57 mandals, 10 municipalities and 729 villages [65]. Krishna, Nagulleru and Chandravanka are the main rivers, and key crops are rice (38 percent), cotton (17 percent), maize ( 9 percent) and chilli $(7.4$ percent); the average annual rainfall is $864 \mathrm{~mm}$ [65]. Farmable land and yield declined considerably in 2018, compared with 2017, in both Krishna and Guntur districts, due to rapid urbanisation. The climate has 
a combination of milder winter and extreme hot summers. This year records showed that extreme summer temperatures extended for another month, due the climatic changes.

\subsection{Key Agriculture Issues}

Agriculture in CAP has been facing a multitude of problems deriving from both natural and anthropogenic hazards, such as sea level rise, cyclones, saltwater intrusions, increasing population and a lack of strong agricultural policy and procedures $[53,61]$. Increased salinity from saltwater intrusion is a huge threat to the population and public health, through its impacts on farming, infrastructure, coastal ecosystems and water used for both domestic and commercial purposes [66-68].

Agriculture is the main and/or only source of income for a majority of the farmers in CAP especially in rural areas. Frequent and intense cyclones generate huge impacts on the farmlands and reduces agriculture production $[68,69]$, particularly rice yields [70]. Due to the geographical location and low-lying topology, several coastal areas are frequently inundated by flood waters; subsequently, several varieties of crops often result in lower quality grains/crops in lower quantities [71]. These issues are becoming a substantial challenge in this region, as it impacts the local and sub local economies. Land-use changes due to rapid migration to coastal areas, monoculture farming, redevelopment and unauthorised fish farms have caused low and unstable food production in several parts of CAP [72,73]. Even though the CAP has been recognised as one of the most highly productive and fertile riverine and coastal areas for agriculture by the AP government, it often suffers from low grain production, due to climate vulnerability and natural disasters [74]. The construction of new bridges on Krishna River, tourism development around the rivers and poor infrastructure has severely damaged the ecological system of this coastal agricultural region, making it even more vulnerable. Various technological innovations have enabled the farming sector to become more efficient and productive in rural India, though the amount of agricultural land and number of farmers has been dwindling year by year in CAP. All these issues warrant in-depth research on agricultural vulnerability in the CAP region.

\section{Methodology}

\subsection{Data and Methods}

Drawing lessons from previous studies highlighted in the previous section, we argue that as agriculture and cropping patterns are exposed to differential climate-led hazards, their vulnerability is determined by the broader dimensions of people, their characteristics, and socioeconomic or non-climatic factors. The data related to the research objectives of this study were collected from both primary and secondary sources. Two major kinds of data were used in this study: climate variability and cropping pattern.

There is a growing consensus among the scientific community that climate related data should be considered in the analysis of agricultural vulnerability, as such a consideration would enable the identification of hot-spot areas that need immediate intervention. Accordingly, the meteorological data such as daily/monthly/annual temperature and rainfall was collected from the Indian Meteorology Department (IMD) for the period of 1919-2002 (Figure 2). This data was then analysed to assess the magnitude and extent of climate change for the selected districts in CAP. Trend analysis was carried out to see the pattern of change in climatic variables. Descriptive statistics (average maximum and minimum) were used to analyse temperatures and rainfall for varying periods in the selected districts. Average, arithmetic mean and percentage were calculated for the purpose of comparison between different districts.

Cropping pattern and information of agriculture in the case study districts are important to understand the characteristics of agriculture vulnerability to the risks of climate variability and the coping capability of the farmers in the region. The selection of crops was done through 12 quantitative surveys, five workshops and several field visits in 22 case study sites in Krishna and Guntur districts (mostly in coastal and riverine agricultural areas), between November 2018 and June 2019 (Figures 3 
and 4). A paper-based questionnaire consisting of 15 questions (written in English) was supplied to the farmers. The majority of the farmers were able to read and understand the questionnaire. Translation into the local language (Telugu) was also offered to farmers who were not confident at reading the English version of the questionnaire. The survey questionnaire had sets of questions to identify information about crops, cropping patterns, water variability and irrigation, and government subsidies (refer to appendix for more detail).
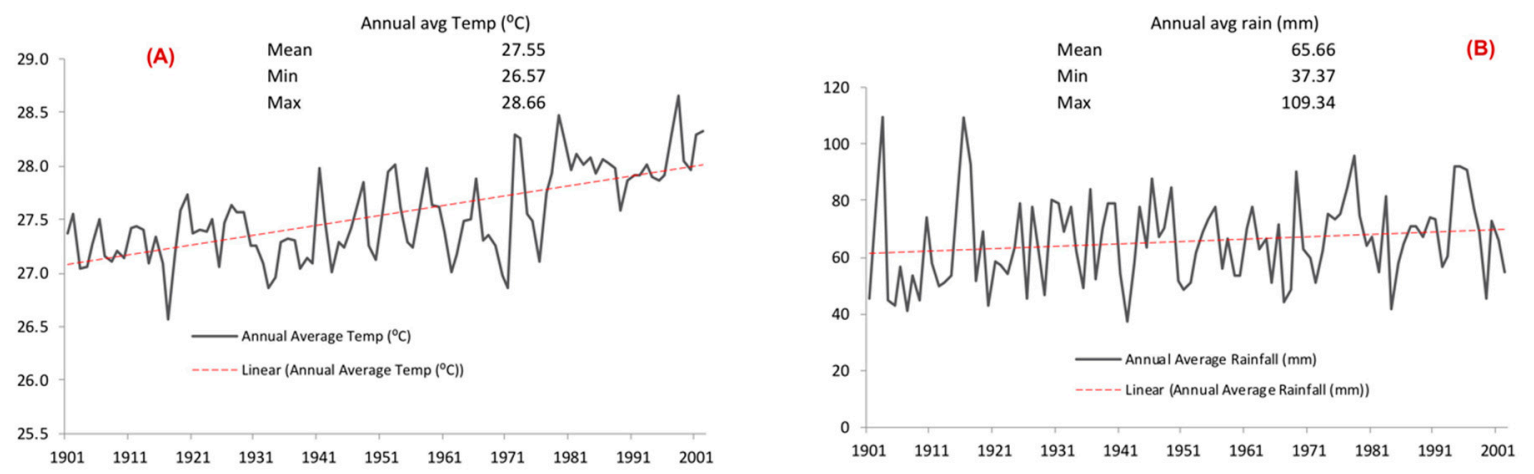

Figure 2. (A,B) Temperatures and rainfall trends (annual) in Guntur and Krishna districts for the period 1919-2002.

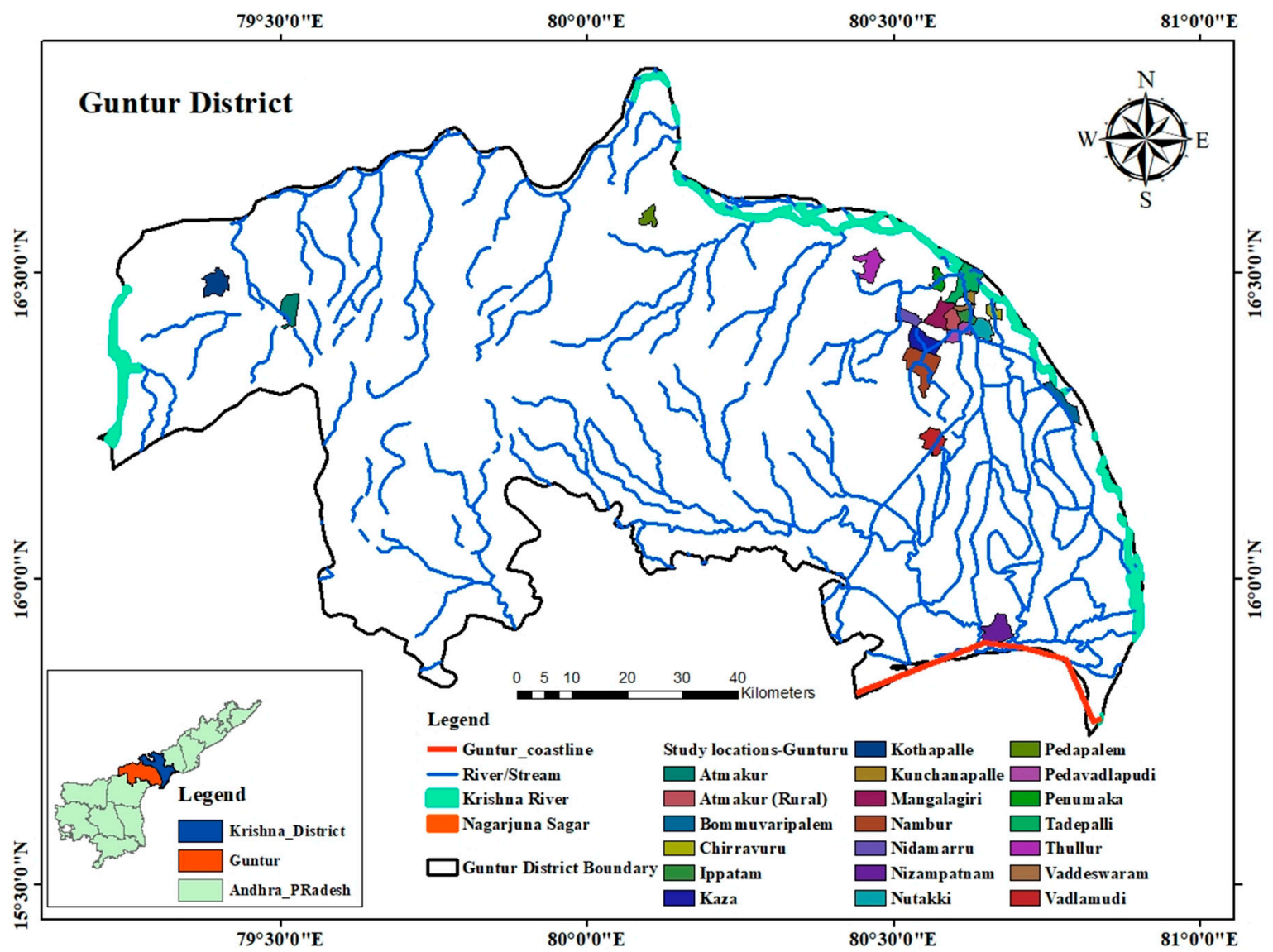

Figure 3. Case study areas in the Guntur district. 


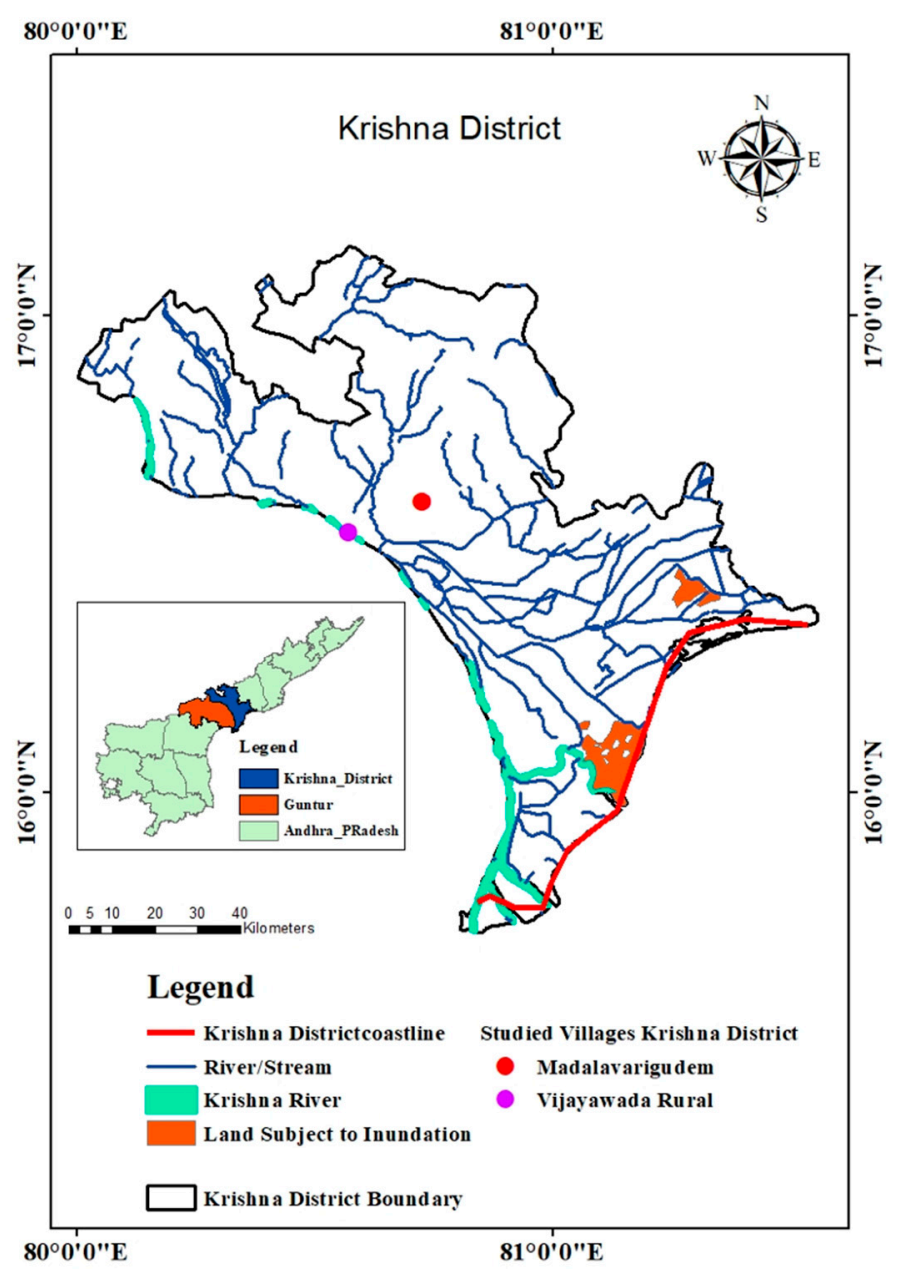

Figure 4. Case study areas in the Krishna district.

Along with this, five workshops (consisting of unstructured dialogue) were conducted with the famers, and several field site visits were made to observe various crop varieties in different locations. The primary author of this paper met more than 1000 farmers to identify the crops grown in the case study areas. Agricultural measurements were also conducted for each of the 22 case sites, using ArcGIS to study the cropping intensity. The farmers who participated in the survey and workshops typically managed between 0.5 to 5 hectares of agricultural land and grew (in total) over 50 varieties of crops. Simultaneously, qualitative data on the impact of agricultural losses on farmers' lives was also collected through personal interviews.

\subsection{Parameters/Indicators}

The raw data collected from the fieldwork was first processed and categorised into six different categories with respect to crops. Subsequently, the six categories of crops for the present study were arranged in a tabular form (Table 3). The research identified that in some sites such as Pedavadlapudi, Chirravuru, Revendra Padu, Pedapalem, Kotta Palem, Kunchanapalli, farmers were farming 2-3 crops in their fields in three seasons (Kharif, Rabi, Ziad) per year. While, some farmers in other sites were growing two crops at the same time (as inner crops such as Banana with Bitter or Ridge gourd, Ridge gourd with Lady's fingers). The inclusion of these issues for the AGCVI was applied to 22 case study sites. 
Table 3. Crop varieties farmed in Krishna and Guntur districts.

\begin{tabular}{cccccc}
\hline Vegetable Crops & Leafy Vegetable Crops & Fruit Crops & Food Grain Crops & Flower Crops & Other Crops \\
\hline Beans & Amaranthus leaves & Groundnut & Corn & Mary gold & Rose \\
Colocasia & Coriander & Guava & Maize & Jotton \\
Cucumber & Chinese Spinach & Banana & Rice & Jasmin & Jute \\
Cauliflower & Curry leaves & Mango & Sapota & Jasminum & Mulberry \\
Cabbage & Mint & Papaya & & Lily & Betel leaves \\
Citrus & Sour Spinach & & & \\
Chillies & & & & \\
Drumstick & & & & \\
Green Gram & & & & \\
Bottle gourd & & & & \\
Brinjal & & & \\
Black gram & & & & \\
Bitter gourd & & & \\
Lady fingers & & & \\
Onion & & & \\
Ridge gourd & & & & \\
Tomato & & & & \\
Tapoica & & & \\
Turmeric & & & \\
Ivy gourd & & & \\
Teasel gourd & & & \\
Yam & & & \\
\hline
\end{tabular}

Later, the trend analysis of the climatic data was carried out to determine the magnitude, direction and significance of the trends in annual and seasonal rainfall and temperature for each sample district (Figure 2). A trend analysis of the climatic data reveal that temperature underwent an increasing trend in both districts during the last century. In particular, around the 1970s, a sharp increase was observed in both districts. Rainfall shows a gradual but insignificant trend of increase. Increases in temperature could result in higher evaporation rates, further resulting in higher water demand from the agricultural sector. In majority of the case study sites, especially in the Guntur district, water availability is good; however, higher temperatures and extended summers impact the crops' yields and farmers' economic status. Based on these trends and themes, the centurial fluctuations in the agriculture sector were estimated for both districts.

Finally, based on the data collected from the farmers through questionnaire, field visits and workshops, temperatures and rainfall trend analysis and natural disasters impact severity, the six key categories of crops were selected as six key parameters (Table 4).

Table 4. Newly established parameters.

\begin{tabular}{ccc}
\hline Number & Parameters & Designated Symbol for AGCVI \\
\hline 1 & Fruit crops & $\mathrm{a}$ \\
2 & Vegetable crops & $\mathrm{b}$ \\
3 & Flower crops & $\mathrm{c}$ \\
4 & Leafy vegetable crops & $\mathrm{d}$ \\
5 & Food grain crops & $\mathrm{e}$ \\
6 & Other crops & $\mathrm{f}$ \\
\hline
\end{tabular}

The AGCVI parameters' vulnerability threshold (Table 5) was derived from the analysis of information obtained from farmer's discussions and their economic statistics (89 percent of farmers shared data from their bills, which relate how much is spent for the farm in a particular year, and how much they earned through the crop production).

The current research considered the data from crop yield damage due to climate change and natural disasters in the previous ten years. These statistics were compared with AP Government's statistics. The results show that there was a significant difference between official data and farmers' data. For example, some farmers suffered a low crop yield, but government official statistics recorded a higher 
yield; this could be due to different market rates at local, regional and national levels. Furthermore, some farmers sell their products through unofficial channels because of the lack of transportation facilities, and agriculture is only their source of income. These statistics are often not included in government official reports, due to the lack of proper communication.

Table 5. Parameter's ratings associated with varying thresholds of vulnerability.

\begin{tabular}{ccccccc}
\hline \multirow{2}{*}{ No. } & Agricultural & \multirow{2}{*}{$\begin{array}{c}\text { Designated } \\
\text { Parameters }\end{array}$} & Symbol for AGCVI & \multicolumn{4}{c}{ Vulnerability Threshold (Emillions) } \\
\cline { 4 - 7 } & & Low (1) & Moderate (2) & High (3) & Very High (4) \\
\hline 1 & Fruit crops & $\mathrm{a}$ & $<0.5$ & $0.5-1.5$ & $>1.5-2.5$ & $>2.5$ \\
2 & Vegetable crops & $\mathrm{b}$ & $<1.5$ & $1.5-2.5$ & $>2.5-3.2$ & $>3.2$ \\
3 & Flower crops & $\mathrm{C}$ & $<0.4$ & $0.4-1.2$ & $>1.2-2.4$ & $>2.4$ \\
4 & Leafy vegetable crops & $\mathrm{d}$ & $<1.0$ & $1.0-2.0$ & $>2-3.1 .0$ & $>3.1$ \\
5 & Food grain crops & $\mathrm{e}$ & $<0.4$ & $0.4-1.1$ & $>1.1-1.5$ & $>1.5$ \\
6 & Other crops & $\mathrm{f}$ & $<0.6$ & $0.6-1.2$ & $>1.2-2.2$ & $>2.2$ \\
\hline
\end{tabular}

Official statistical records contain information concerning crop yields, purchase and revenue records, farmer numbers in particular fields, farmer's economic status (how much farmland they have and how many crop varieties they usually cultivate per year), soil fertility test results, supplied fertilisers, labour use, seasonal pattern crop insurance etc. These documents helped to determine the threshold values in a systematic way. Consideration of all these issues lead to the current study including the farmer's statistics as they are more accurate and frequently updated.

The finalisation of the threshold of the AGCVI required that each of the selected agricultural vulnerability parameters be specific and contribute similarly (equally) towards the agricultural coastal vulnerability measurement. Accordingly, the parameters are equally weighted on a measurement scale $(1-4)$.

\subsection{Index}

After the identification and development of the 6 crop parameters and vulnerability thresholds, the Agricultural Coastal Vulnerability Index (AGCVI) was developed. For the index development, a simple method with equal weights as proposed by Kantamaneni et al. [60] was adopted for this study. Equal weight method is easy to calculate and simple to understand, and therefore it has even been adopted for the calculation of the Human Development Index by the United Nations (UN). Kantamaneni et al. [60] established the physical coastal vulnerability index (PCVI), the economic coastal vulnerability index (ECVI) and the combined coastal vulnerability index (CCVI) indices to evaluate the coastal vulnerability of the UK using a combination of novel and existing physical and economic parameters.

In this study [60], the coastline of 11 case study areas in the UK was divided into $1 \mathrm{~km}$ and $0.5 \mathrm{~km}$ cells, and, subsequently, relative vulnerability was ranked according to low, moderate, high and very high risks. The index helped to identify relative coastal risk along diverse segments of the UK coastline. However, this new study did not take existing parameters and their thresholds from Kantamaneni et al. [60]. Instead, this current study uses the newly established components and parameters from the case study empirical data and ground analysis.

In total, 152 hectares were considered for the assessment. Three hectares were excluded from the analysis, because these lands bordered across different ownerships. In total, 149 hectares were divided into 1-hectare cell i.e., 149 cells. A transect baseline was drawn across the frontage of each of the identified agricultural coastal vulnerability sites and a 1-hectare grid (or cell) was drawn inland from the baseline (Figure 5). Comprehensive measurements based upon each parameter were recorded within each identified cell. 

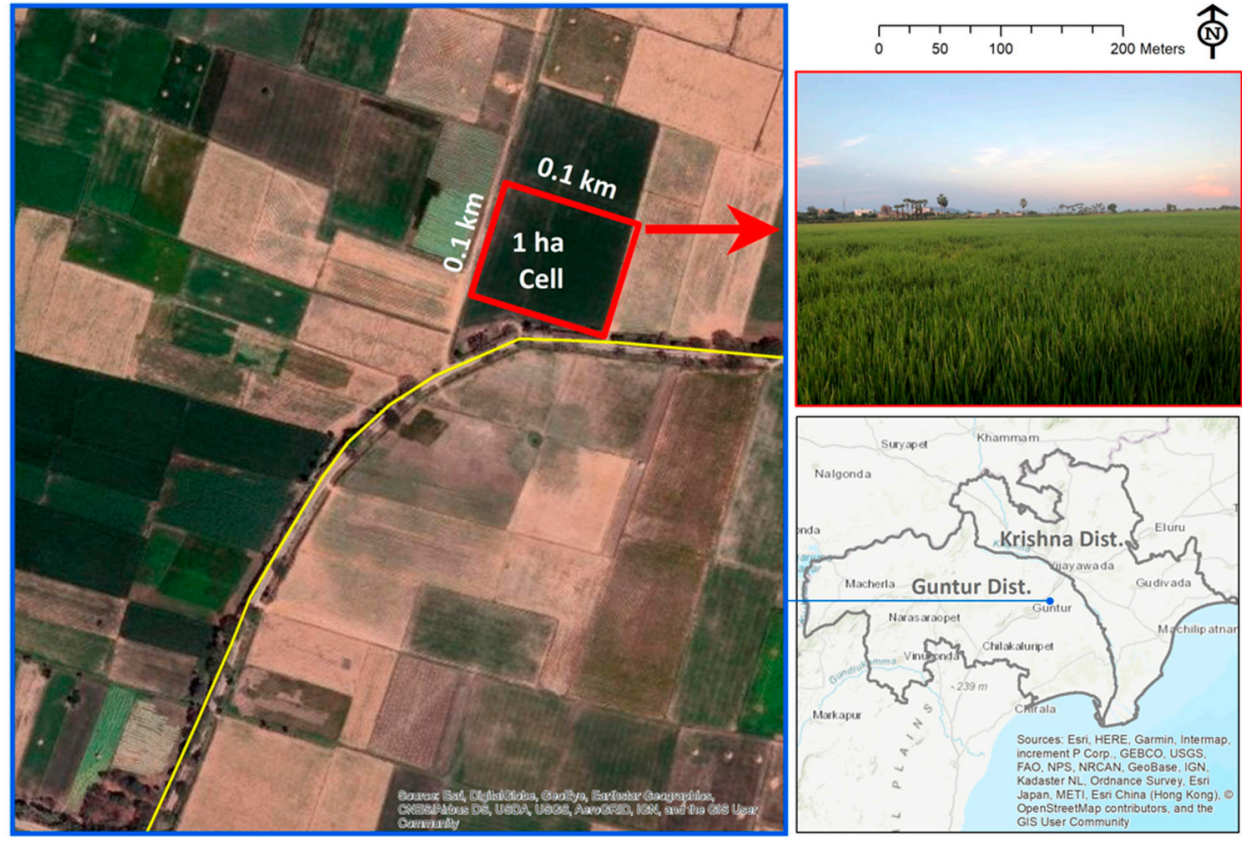

Figure 5. Transect line and 1-hectare agricultural coastal cell.

To evaluate agriculture vulnerability, each and every individual measurement was compared and assigned a rank-from low (1), moderate (2), high (3) to very high (4) vulnerability. Once the rankings had been allocated, these values were then summed to provide a relative AGCVI (vulnerability index) score, where

$$
A G C V I=a+b+c+d+e+f
$$

where each letter was equal to the ranking score for each parameter (ranging from 6 to 24). Then, these scores were used to classify the sites in terms of agricultural vulnerability (Table 6).

Table 6. Total relative vulnerability score.

\begin{tabular}{cc}
\hline Total Relative Vulnerability Score & Vulnerability \\
\hline$<11$ & Low \\
$11-14$ & Moderate \\
$15-18$ & High \\
$19-24$ & Very High \\
\hline
\end{tabular}

\section{Results}

\subsection{Analysis of the AGCVI Values}

Agricultural coastal cell measurements were carried out for each and every individual location, in accordance with the procedures explained in the methodology section. Each agricultural field was divided into 1-hectare cells and in total 149 hectares were divided into 149 cells (Table 7). In Guntur district ('district' is synonymous with a 'county' in other countries) 20 sites were associated with circa 143 hectares of coast agricultural land (143 cells), and the two sites in Krishna district were associated with circa six hectares of land (six cells). 
Table 7. Site locations and numbers of associated cells.

\begin{tabular}{|c|c|c|c|c|}
\hline Number & Site Name & $\begin{array}{l}\text { Agricultural Land Length in } \\
\text { Coastal Areas Considered }\end{array}$ & Cell Range & Total Assessed Cells \\
\hline & Guntur district -sites & & & \\
\hline 1 & Nutakki & 12 & $1-12$ & 12 \\
\hline 2 & Vadlapudi & 21 & $13-33$ & 21 \\
\hline 3 & Pedapalem & 4 & $34-37$ & 4 \\
\hline 4 & Nidamarru & 2 & $38-39$ & 2 \\
\hline 5 & Aatmakuru & 4 & $40-43$ & 4 \\
\hline 6 & Revendrapadu & 3 & $44-46$ & 3 \\
\hline 7 & Namburu & 38 & $47-84$ & 38 \\
\hline 8 & Kaza & 4 & $85-88$ & 4 \\
\hline 9 & Kunchanapalli & 4 & 89-92 & 4 \\
\hline 10 & Vaddeswaram & 2 & $93-94$ & 2 \\
\hline 11 & Kotha Palem & 4 & $95-98$ & 4 \\
\hline 12 & Ippatam & 4 & 99102 & 4 \\
\hline 13 & Nizampatnam & 2 & 103-104 & 2 \\
\hline 14 & Penumaka & 4 & $105-108$ & 4 \\
\hline 15 & Paturu & 4 & $109-112$ & 4 \\
\hline 16 & Tadepalli & 8 & $113-120$ & 8 \\
\hline 17 & Bommivani palem & 4 & $121-124$ & 4 \\
\hline 18 & Chirravuru & 8 & $125-132$ & 8 \\
\hline 19 & Tulluru & 9 & $133-141$ & 9 \\
\hline \multirow[t]{2}{*}{20} & Mangalagiri & 2 & $142-143$ & 2 \\
\hline & Krishna district -sites & & & \\
\hline 21 & Madalavari gudem & 4 & $144-147$ & 4 \\
\hline \multirow[t]{2}{*}{22} & Vijayawada & 2 & $148-149$ & 2 \\
\hline & & Total Hectares-149 & & Total Cells-149 \\
\hline
\end{tabular}

\subsection{Application of Agricultural Coastal Vulnerability Scores}

There are substantial variations between the 149 cells with respect to their AGCVI values (Figure 6). The average CVI score for fruit crops was 2.7, and the highest was four, which was recorded for 55 cells (37 percent). Most of the highest values were recorded at the Peda Vadlapudi and Pedapalem sites, which are located in Guntur district. The lowest score was one, and 44 (29 percent) cells received this value. The majority of these lowest values were recorded at the Namburu site (Guntur district). The CVI scores for the fruit crop parameter clearly specified that the sites in Guntur district have greater vulnerability with respect to this parameter than those in the Krishna district sites.

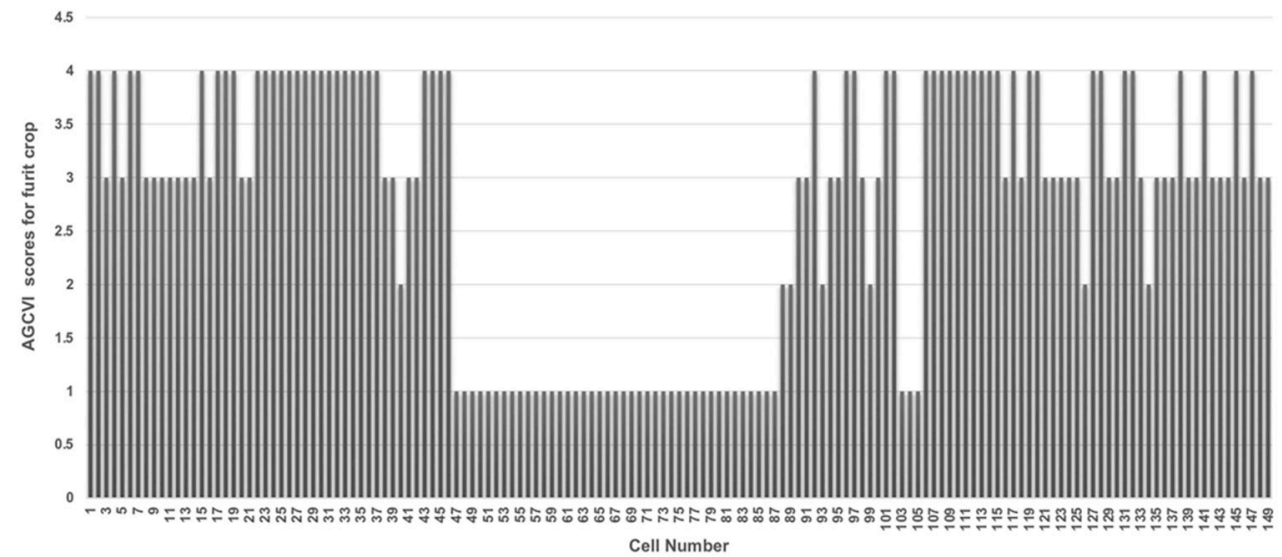

Figure 6. Agricultural Coastal Vulnerability Index (AGCVI) scores for fruit crops.

Significant variance exists among the vegetable crop CVI values for the 149 cells (Figure 7). The average CVI score was 2.4, and the highest score was four, which was recorded for 28 cells (19 percent). Those that received higher scores were found at the Revendrapadu and Kunchanapalli sites (Guntur district). The lowest score was one, and 42 cells (28 percent) received this score. 


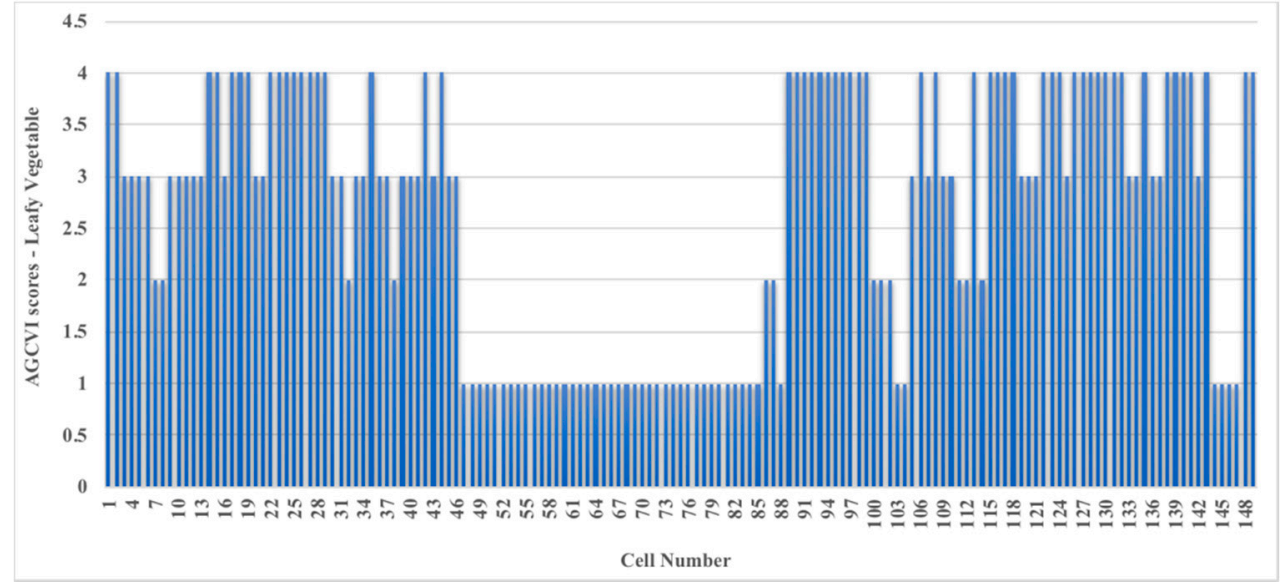

Figure 7. AGCVI scores for vegetable crops.

While the average CVI score for flower crop was 2.7 (Figure 8), the highest score was four, which was recorded for 59 cells (39.5 percent). Most of the highest values were recorded for Nutakki and Peda Vadlapudi (Guntur district). The lowest value is zero, which was recorded at the Madalavari (Krishna district) Gudem site, and all four cells of this site received this score. The CVI scores for flower crops reflect site specific variations.

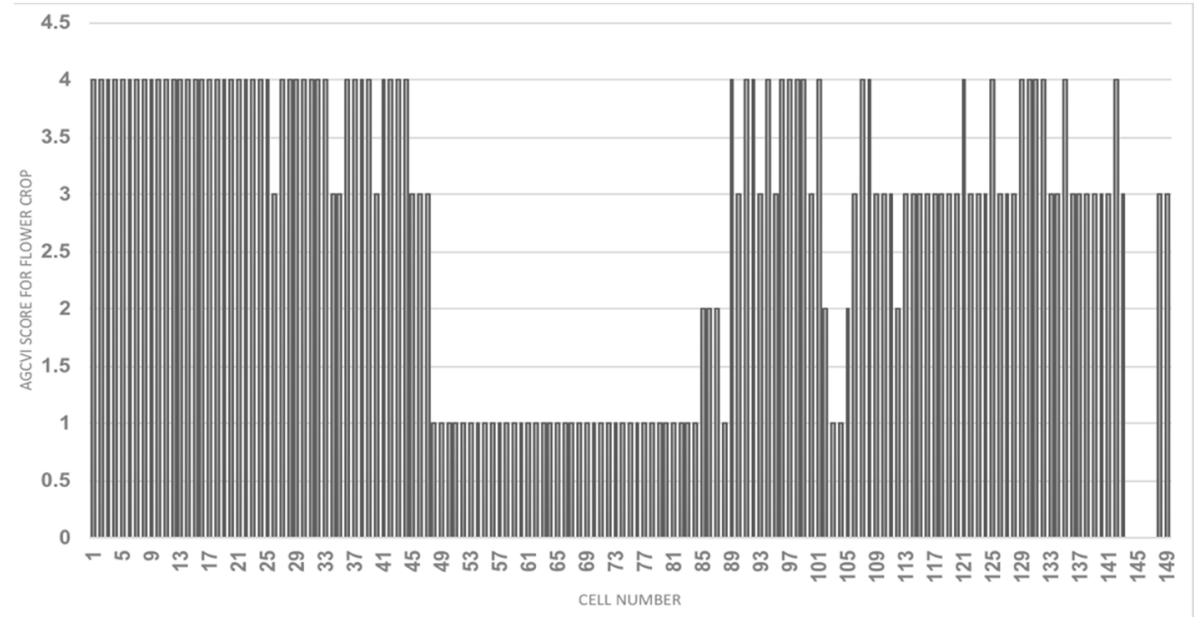

Figure 8. Graphical representation of AGCVI scores for flower crops.

Considerable variance exists among the CVI values for leafy vegetable crops (Figure 9). The average CVI score was 2.6, and the highest was four, which was recorded for 54 cells (36 percent). Most of the highest values were recorded at the Peda Vadlapudi and Chirravuru sites (Guntur district). This lowest CVI value was one, and 46 cells received this score and this lowest value was recorded for the Namburu site (Guntur district). The CVI scores for leafy vegetable crops clearly indicate that Guntur district has the highest vulnerability in terms of leafy vegetable crops.

The average CVI score for food grain crops was 3.3, and the highest CVI score was four, which was recorded for 69 cells ( 46 percent) (Figure 10). The highest values were mainly recorded at the Namburu, Nutakki sites (Guntur district). The lowest score was one, which was recorded for only two cells. A considerable variance exists among the other crops CVI values for the 149 cells. 


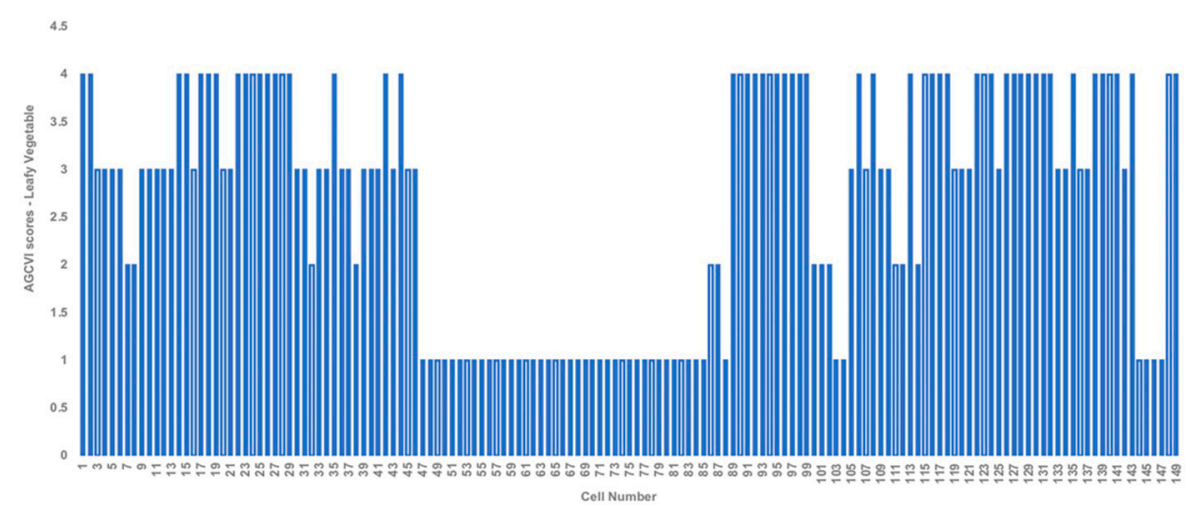

Figure 9. Graphical representation of AGCVI scores for leafy vegetable.

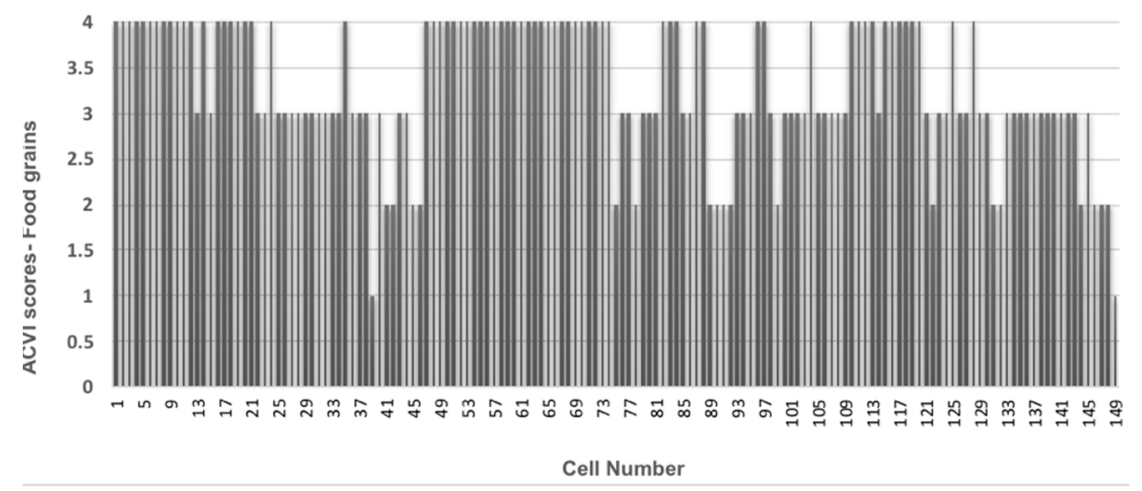

Figure 10. Graphical representation of AGCVI scores for food grain crops.

The average CVI score for other crops was 2.3, and the highest CVI score was four, which was recorded for 21 cells (Figure 11). Most of the highest values were recorded at Nutakki and Peda Vadlapudi. Of the sites surveyed, the CVI scores for food grains and leafy vegetables suggest that locations in Guntur district take more coastal agricultural protection measures than those in Krishna district.

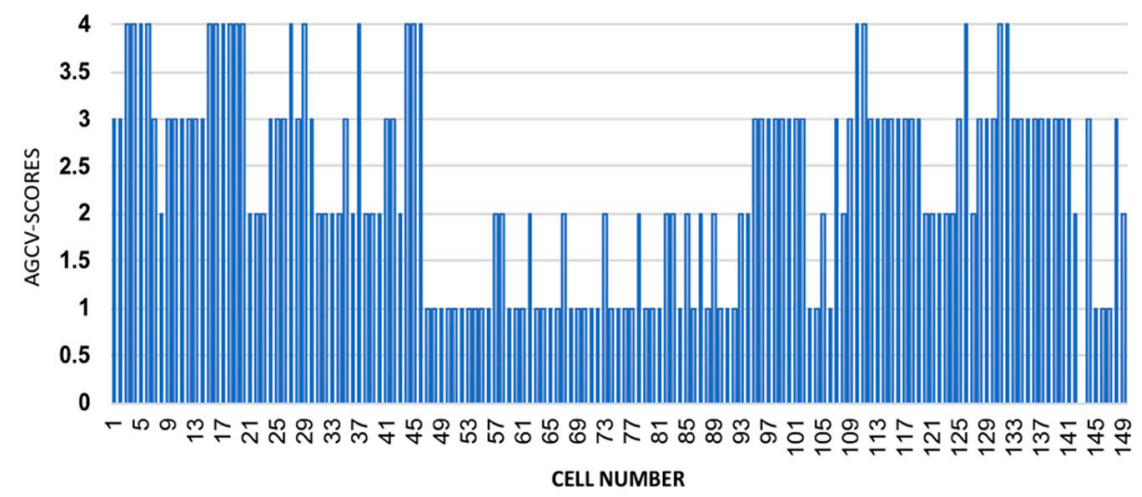

Figure 11. Graphical representation of AGCVI scores for other crops.

\subsection{Overall AGCVI Scores and Trends}

Considerable variations exist between the 149 AGCVI values as shown in Figure 12. The greater number of cells fall between very high and high categories. The average value was 16.21, which corresponds to the high category. However, the maximum AGCVI value (23) was obtained for the Peda Vadlapudi and Chirravuru sites (Guntur district), while the lowest (seven) was obtained for the Namburu site. 


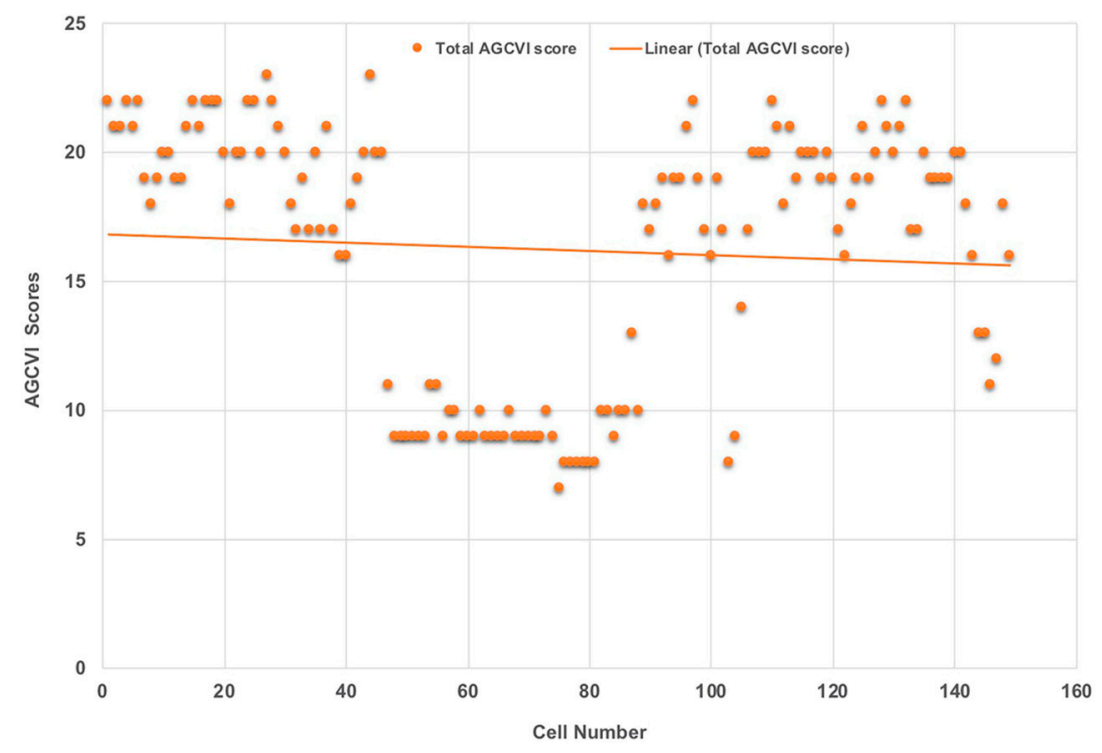

Figure 12. Overall trend of AGCVI values.

As shown in Figure 13, more than 48 percent of cells were rated as having very high vulnerability (19-24), and 19 percent of the cells were rated as highly vulnerable (16-18). In addition, only six percent of the cells were found to be moderately vulnerable (12-15). The overall CVI scores clearly indicated that 67 percent of cells have either extremely high or high agricultural vulnerability in the selected 22 case study areas in Coastal Andhra Pradesh (Krishna and Guntur districts).

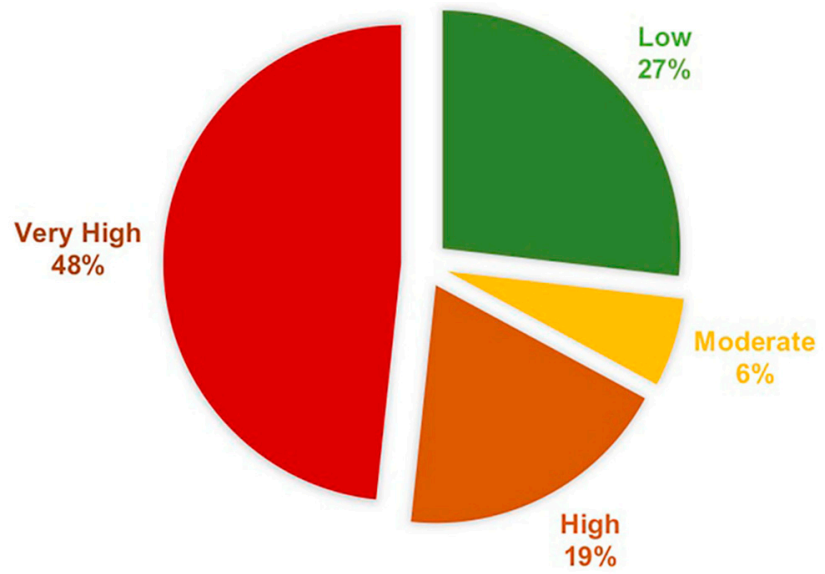

Figure 13. Overall AGCVI scores distribution.

AGCVI values reveal the overall vulnerability and suggest that the Guntur district case study locations may be more vulnerable than those in Krishan district because of more crops grown in three seasons. Some agricultural cells have few or no flower crops (Madalavari Gudem-Krishna district) and some other sites such as Namburu have huge number of food grains in 38 cells.

\section{Discussion}

\subsection{Agricultural Vulnerability from a Physiological and Environmental Perspective}

The present study established the novel Agricultural Coastal Vulnerability Index (AGCVI) with six new parameters: fruit crops, vegetable crops, flower crops, leafy vegetable crops, food grain crops and other crops. The selection of agricultural parameters can be complicated, due to the number of crops within specific coastal and agricultural environments. However, these parameters were developed 
by conducting surveys and workshops for farmers in selected case study areas between November 2018 and June 2019 in the CAP region. This method of parameters is a new approach to agricultural vulnerability assessment. The literature on agricultural coastal vulnerability is very limited in India, and this is perhaps the first index which evaluates the coastal vulnerability at the sub-regional level in India.

The findings of this research show that in some agricultural sites, such as Madalavarigudem (Krishna district) and Vijayawada, (Krishna district), there are no food grain crops, because of unsuitable geographical locations, poor soil suitability or lack of appropriate water irrigation facilities. Before planning the farming in a particular area, the famers consider water availability and water quality [75]. In Madalavari Gudem (Krishna district), farmers are always keen to farm fruit (mango), even though they suffer from huge losses due to frequent natural disaster events such as cyclones (Figure 14). Cyclones result in severe destruction to the agricultural farms in coastal areas especially in tropical countries [76]. High climate variability increases the natural disasters' number, and ultimately leads to more fiscal damage [77].
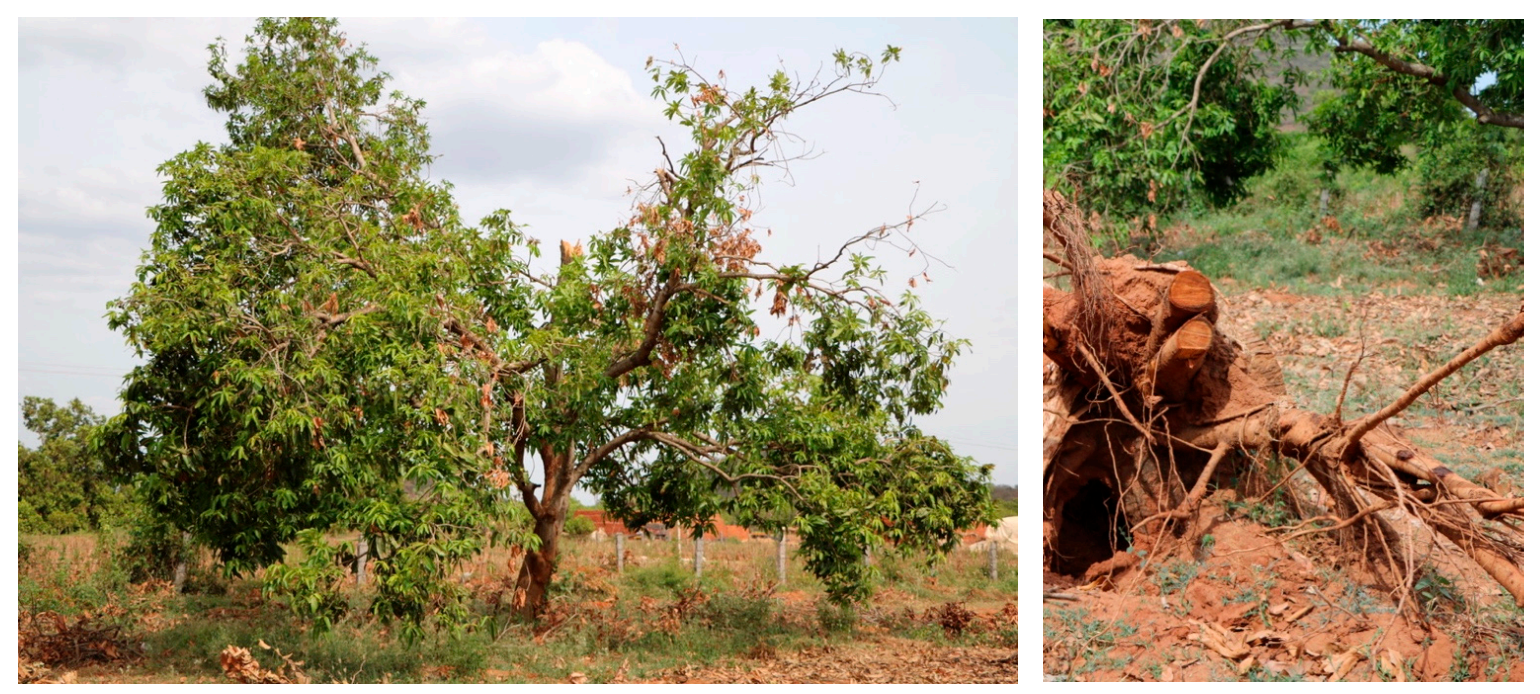

Figure 14. Cyclone Fani impacts on a mango garden in Madalavarigudem (June 2019).

The degree of the impact of climate change and other natural hazards in agriculture depends on the level of susceptibility or exposure of farmers to these effects. Several fruit crops were impacted by cyclone Fani in CAP in the case study areas in May 2019. In Chirravuru (Guntur district) banana crops were severely damaged due to Cyclone Fani, and several farmers lost entire crops (Figure 15) and did not get an insurance payment for that damage. Due to these unexpected weather events, the farmers' lives were negatively impacted socially and economically. Crop change may be an appropriate alternative for reducing vulnerability or economic insurance for evading the influence of risk exposure [78]. In many regions across the world, the circumstances that give rise to flooding or crop failure are expected to be intensified by climate change in the coming years [79].

The highest coastal vulnerability was recorded in the Peda Vadlapudi and Chirravuru sites, because of multiple crop (flower, fruit and vegetable) cultivation and rotations per year. Cyclones, flooding, strong winds and erosion are major issues in the selected case study areas, and these are impacting the coastal agricultural areas. In locations such as Tulluru, Vijayawada and Kunchanapalli, the addition of new urban developments (Figure 16) will further increase pressure, potentially leading to even greater economic losses from flooding and storm damage. Agricultural lands, which serve as the main source of livelihood, have been intruded upon by the urban development processes in recent years in CAP. Additionally, the pressures of rapid urbanisation have adverse impacts on (mainly) poorer farming communities, especially in coastal regions [80]. 


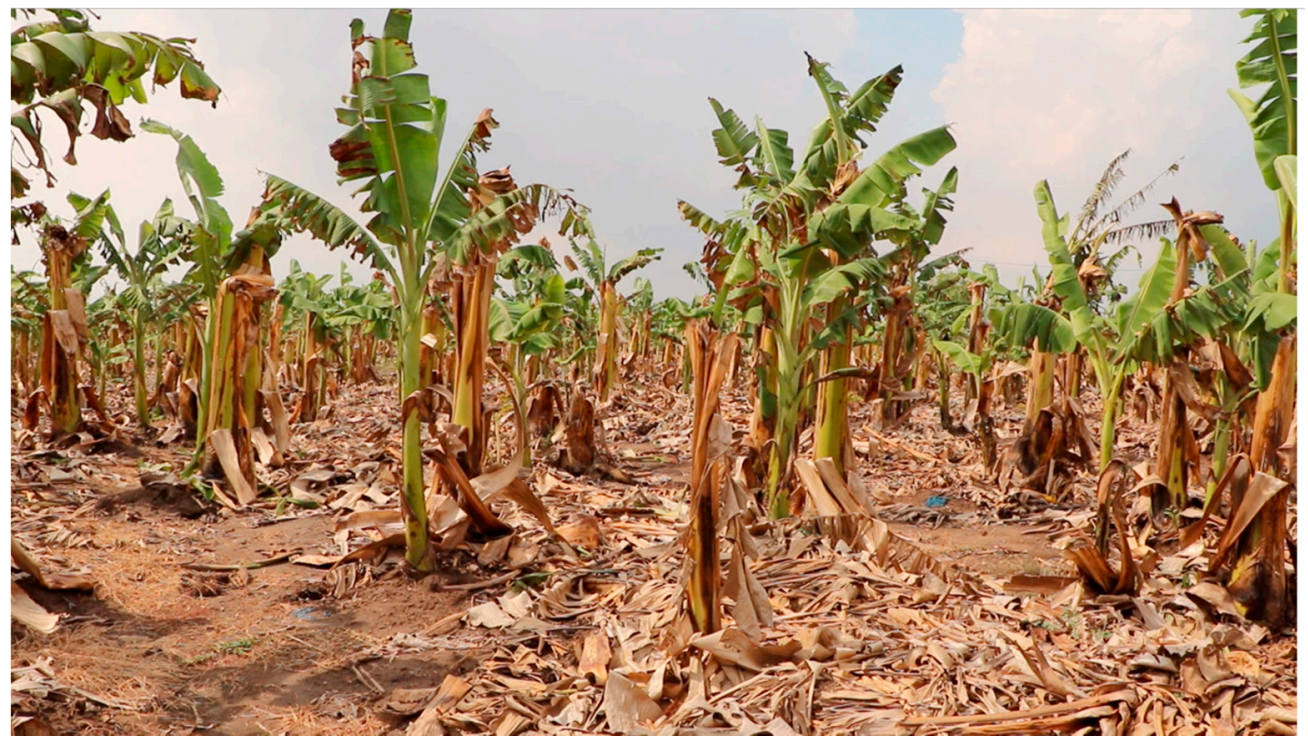

Figure 15. Cyclone Fani impacts on Banana crop in Chirravuru-June 2019.

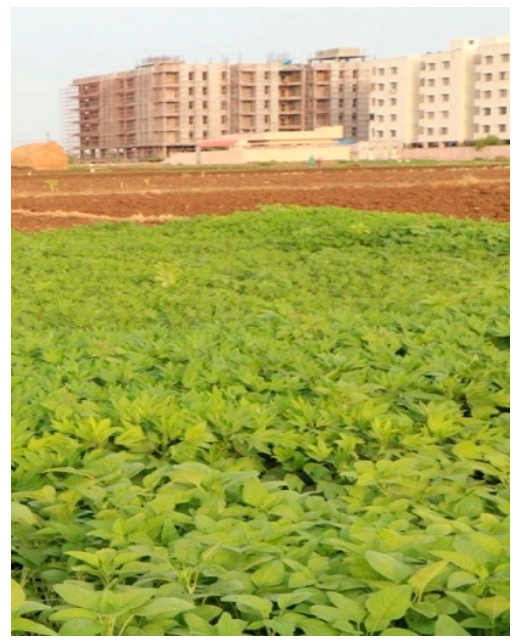

Figure 16. New urban development in Kunchanapalli.

The main challenge from rapid urban growth is changing land use patterns. Nonetheless, whilst urbanisation is necessary, it does not need to destroy rural farming; there is a need for more careful consideration and balancing of urban development and protection of agricultural space. Whilst ensuring necessary and sustainable urban development take place, policymakers should focus more attention on the protection of agricultural lands, as these are the key source of economic livelihood in CAP.

The current study also found that rice is not a commercial crop in the majority of study areas, and some farmers even expressed that they are no longer interested in farming, because of unexpected losses due to natural disasters and lack of support from the government. Though India ranks third in the production of rice, its yield is less than China, Brazil and the United States [81]. On the evidence of overall trends, AGCVI index scores showed the diverse trends for six crop varieties, of which the fruit crops, banana and in food grains rice are the most vulnerable crops.

\subsection{Agricultural Vulnerability from a Socio-Economic and Cultural Perspective}

In CAP, climate change creates effects not only in agriculture but also in farmers' personal lives. During the data collection process in the CAP region, many young farmers shared novel insights into the changing socio-economic aspects of agricultural life particularly about changing marital 
practices. The majority of the farmers said that they are not getting married because of their farming profession, which is leading to a marriage crisis. The worsening fluctuations in climatic conditions are leading to many young farmers becoming middle-aged bachelors. In Krishna and Guntur districts, the majority of farmers are male and earn low to medium ranged incomes, and they typically have between one to five acres of farming land. In India, the majority of marriages are arranged; however, due to the increasing uncertainty of farmers' incomes, many parents no longer want farmers as their son-in-law. Increasingly the eligible women instead prefer to marry employees (particularly government employees), who earn a stable monthly income.

One of the young farmers from Guntur district said: "I am searching for a suitable bride for eight years and still not yet married".

Another farmer, now is in his early 40s, said that: "I did not get a bride even though I offered a financial incentive" (known locally as a Kanyasulkam - the traditional custom of a gift to the future bride).

Many of the farmers remain as bachelors, due to changes in the brides' preferences as a corollary of the climate crisis. These circumstances explain that in both districts, agriculture is becoming an increasingly uncertain, precarious and undesirable profession, due to the climate crisis. A significant number of farmers are effectively forced to migrate to other regions (or states in their respected regions) in order to cope with the emerging marriage crisis. If the impact of climate change is not minimised in the near future, agriculture will be significantly affected, as well as harming many traditional cultural practices.

The focus on climate change hitherto has mostly focused on the impacts on the natural environment. This research highlights for the first time that social and cultural changes are also occurring as a consequence of environmental damage. The climate crisis is linked to a marriage crisis, in a place where over a billion of the world's population still have arranged marriages, the social and cultural consequences of climate change are just beginning to be understood and experienced; but further research is required to better understand this emerging issue.

\section{Conclusions}

\subsection{Main Research Findings}

The coastal agricultural sector in low-to-middle income countries faces many challenges, such as rising demand, pressures from natural disasters, and dealing with the uncertainties of climatic changes. Upgraded information and knowledge is vital to generate applicable measures to cope with climate-induced risks and reduce agriculture vulnerability. Accordingly, the current study measured the coastal agricultural vulnerability of 22 case study areas located in Andhra Pradesh (AP) (Guntur and Krishna districts), the state with the second longest coastline in India, by the development of a novel index, namely the (Agricultural Coastal Vulnerability Index AGCVI). The AGCVI was established with six new parameters that were evaluated on an agricultural site-by-site basis and then applied to the 22 identified coastal agricultural areas. The results revealed that agricultural vulnerability varies across the sites. Current Coastal Andhra Pradesh (CAP) coastal vulnerability is relatively uneven across the 22 sites, and the highest score was identified in the Pedavadlapudi and Chirravuru sites. The lowest scores were identified at the Nmaburu and Kaza sites, even though they have the highest food grain vulnerability. The results also show that food grain crops, flower crop and fruit crops are the most vulnerable; leafy vegetable crops and flower crops are the most profitable crops compared to other crops. Rice crops are no longer a profitable crop in the case study sites. Fluctuations in climatic conditions, natural disasters such as floods and cyclones in non-rainy seasons and strong winds are the main reasons for the agricultural vulnerability in the selected case study areas. Overall, the climate crisis conditions are negatively affecting the farmers' economic resources, leading to profound disruption to social life and cultural practices within this community. 


\subsection{Policy Implications}

The study results have implications for several policy areas with regard to tackling climate-induced agriculture vulnerability, and for preparing farmers to cope up with the risks from exposure to climate change. The results of the study show that climate change may pose a serious challenge to the agricultural sector in India through changes in rainfall and temperature patterns and an increased frequency of natural disasters such as droughts and floods. Under such circumstances, a large number of small-scale and marginal farmers will be extremely vulnerable to climate change, and so adaptation should be a priority for policy development in India. Furthermore, small-scale and marginal farmers will not be able to cope with the impacts of natural disasters, which will be further exacerbated due to the challenges posed by climate change. Considering these challenges, the following policy recommendations are proposed to support adaptation at household level. First, social protection measures that build on traditional risk diffusion measures, such as borrowings in drought years, crop storage for lean years and accumulation of financial assets are recommended, as they can partially contribute to improving the adaptive capacity of farmers to new climatic changes. Second, policies that promote better access to crop insurance, crop diversity, water harvesting, knowledge and awareness on water conservation practices, providing drought-resistant crop varieties, and improved weather information availability can play an important role in increasing farmers' resilience and ability to adapt to climate change. However, the policies that support crop insurance should not incentivise specific crops, as this will lead to mono-cropping and loss of biodiversity, which, in the long run, may lead to maladaptation (increased vulnerability in subsequent time periods). Finally, best practices and successful examples of sustainable and resilient farming practices in different agro-climatic zones should be identified and scaled-up. Simultaneously, farmers should respond to climate change by investing in risk reduction strategies such as crop diversification, changing cropping patterns and dates, soil and water management techniques and expanding irrigation.

\subsection{Research Challenges and Future Work}

Although the present study has produced some significant and interesting results, there are certain research limitations and challenges that can be improvised for better research in this field. Firstly, due to the dearth of availability of consistent government data on crop yield and revenues for a particular region, it took a lot of time to compile and finalise the data sets. Secondly, significant socio-economic, cultural and caste differences in the 22 case study areas led to challenges in collecting better representative samples. Thirdly, due to limited fieldwork time, the research could not be extended to more areas. Fourthly, the lack of full access to census data on soil fertility and crop cultivation is a major limitation, and could be better addressed in future research. Finally, during the field visits, some regional and sub-regional farmers and authorities did not respond within the timeframe and postponed the meeting events without prior notice. However, most of the vital information was obtained during the stipulated data collection period.

The results of this research can be improved by spatially comparing other vulnerable regions of the state and the country to the present study area. It is further proposed that future work should include 'fuzzy logic' methods to apply a weighting system to parameters. In addition, drone survey data, spatial data and normal survey data could be combined for a better evaluation of agricultural vulnerability research. Additionally, more analysis on updated grey literature and policy reports could be included to analyse agriculture systems in future studies. These research areas could also significantly strengthen the policy implications of this research.

Author Contributions: K.K. designed the study and developed the methodological procedures. K.K. performed field visits, workshops and surveys. K.K. and K.Y. wrote the paper. L.R., K.Y. and L.C.C. modified the manuscript and advised on the results and discussion sections. K.Y. advised on limitations and policy recommendations. All authors have read and agreed to the published version of the manuscript.

Funding: This research was funded by the GCRF (Global Challenges Research Fund), United Kingdom. 
Acknowledgments: Particular acknowledgement is made to Pammi Nitin Sinha and Sudha Rani NVV for their assistance in generating study area maps using MatLab and ArcGIS.

Conflicts of Interest: The authors declare no conflict of interest.

\section{References}

1. World Bank. Agriculture Is Environment. Available online: http://siteresources.worldbank.org/ DATASTATISTICS/Resources/WDI07section3-intro.pdf (accessed on 10 December 2019).

2. Food and Agricultural Organisation (FAO). Integration of Agriculture into Coastal Area Management. Available online: http://www.fao.org/3/W8440e07.htm (accessed on 12 December 2019).

3. Calabi-Floody, M.; Medina, J.; Rumpel, C.; Condron, L.M.; Hernandez, M.; Dumont, M.; de la Luz Mora, M. Smart fertilizers as a strategy for sustainable agriculture. In Advances in Agronomy; Elsevier: Amsterdam, The Netherlands, 2018; Volume 147, pp. 119-157.

4. Kotir, J.H. Climate change and variability in Sub-Saharan Africa: A review of current and future trends and impacts on agriculture and food security. Environ. Dev. Sustain. 2011, 13, 587-605. [CrossRef]

5. Dawson, T.P.; Perryman, A.H.; Osborne, T.M. Modelling impacts of climate change on global food security. Clim. Chang. 2016, 134, 429-440. [CrossRef]

6. D'Amour, C.B.; Reitsma, F.; Baiocchi, G.; Barthel, S.; Güneralp, B.; Erb, K.-H.; Haberl, H.; Creutzig, F.; Seto, K.C. Future urban land expansion and implications for global croplands. Proc. Natl. Acad. Sci. USA 2017, 114, 8939-8944.

7. United Nations (UN). Devastating Impacts of Climate Change Threatening Farm Outputs, Increasing Global Hunger, Delegates Say as Second Committee Takes up Agriculture, Food Security. Available online: https://www.un.org/press/en/2018/gaef3499.doc.htm (accessed on 12 October 2019).

8. Knox, J.; Hess, T.; Daccache, A.; Wheeler, T. Climate change impacts on crop productivity in Africa and South Asia. Environ. Res. Lett. 2012, 7, 034032. [CrossRef]

9. Field, C.B.; Barros, V.R.; Dokken, D.; Mach, K.; Mastrandrea, M.; Bilir, T.; Chatterjee, M.; Ebi, K.; Estrada, Y.; Genova, R. IPCC, 2014: Climate Change 2014: Impacts, Adaptation, and Vulnerability. Part A: Global and Sectoral Aspects. Contribution of Working Group II to the Fifth Assessment Report of the Intergovernmental Panel on Climate Change; Cambridge University Press: Cambridge, UK; New York, NY, USA, 2014.

10. Adger, W.N.; Hughes, T.P.; Folke, C.; Carpenter, S.R.; Rockström, J. Social-ecological resilience to coastal disasters. Science 2005, 309, 1036-1039. [CrossRef] [PubMed]

11. Rasul, G.; Mahmood, A.; Sadiq, A.; Khan, S. Vulnerability of the Indus delta to climate change in Pakistan. Pak. J. Meteorol. 2012, 8, 89-107.

12. Akanda, M.; Howlader, M. Coastal farmers' perception of climate change effects on agriculture at Galachipa Upazila under Patuakhali District of Bangladesh. Glob. J. Sci. Front. Res. Agric. Vet. 2015, 15, 30-39.

13. Huq, N.; Hugé, J.; Boon, E.; Gain, A.K. Climate change impacts in agricultural communities in rural areas of coastal Bangladesh: A tale of many stories. Sustainability 2015, 7, 8437-8460. [CrossRef]

14. Gopalakrishnan, T.; Hasan, M.K.; Haque, A.; Jayasinghe, S.L.; Kumar, L. Sustainability of Coastal Agriculture under Climate Change. Sustainability 2019, 11, 7200. [CrossRef]

15. Geethalakshmi, V.; Manikandan, N.; Sumathi, S.; Bhuvaneswari, K.; Gowtham, R.; Pannerselvam, S. Impact of Climate Change on Coastal Agriculture. Int. J. Econ. Plants 2016, 3, 93-97.

16. Banerjee, S.; Samanta, S.; Chakraborti, P.K. Impact of Climate Change on Coastal Agro-Ecosystems. In Sustainable Agriculture Reviews 33; Springer: Berlin/Heidelberg, Germany, 2018; pp. 115-133.

17. Van Dan, T.; Bond, J.; Thuy, N.T.T. Assessment of Impacts of Climate Change on Agriculture and Fisheries in the Coastal Areas of Thua Thien Hue Province, Vietnam. Agric. Dev. Notes 2018, 8, 1-4.

18. Hoque, M.Z.; Cui, S.; Xu, L.; Islam, I.; Tang, J.; Ding, S. Assessing Agricultural Livelihood Vulnerability to Climate Change in Coastal Bangladesh. Int. J. Environ. Res. Public Health 2019, 16, 4552. [CrossRef] [PubMed]

19. Kareemulla, K.; Venkattakumar, R.; Samuel, M.P. An analysis on agricultural sustainability in India. Curr. Sci. 2017, 112, 258-266. [CrossRef]

20. Natcom, I.; Ministry of Environment and Forests, Government of India. India: Second National Communication to the United Nations Framework Convention on Climate Change. 2013. Available online: http://envfor.nic.in/ (accessed on 10 December 2019). 
21. Auffhammer, M.; Ramanathan, V.; Vincent, J.R. Climate change, the monsoon, and rice yield in India. Clim. Chang. 2012, 111, 411-424. [CrossRef]

22. Cline, W.R. Global Warming and Agriculture: Impact Estimates by Country; Peterson Institute, Columbia University Press: Washington, DC, USA, 2007.

23. Centre for Coastal Zone Management and Coastal Shelter Belt. Coastal States of India. Available online: http://iomenvis.nic.in/index2.aspx?slid=758\&sublinkid=119\&langid=1\&mid=1 (accessed on 1 January 2020).

24. Rosenzweig, C.; Hillel, D. Climate Change and the Global Harvest: Potential Impacts of the Greenhouse Effect on Agriculture; Oxford University Press: Oxford, UK, 1998.

25. Hareau, A.; Hofstadter, R.; Saizar, A. Vulnerability to climate change in Uruguay: Potential impacts on the agricultural and coastal resource sectors and response capabilities. Clim. Res. 1999, 12, 185-193. [CrossRef]

26. Wisner, B.; Luce, H.R. Disaster vulnerability: Scale, power and daily life. GeoJournal 1993, 30, 127-140. [CrossRef]

27. Blaikie, P.; Cannon, T.; Davis, I.; Wisner, B. At Risk: Natural Hazards, People's Vulnerability and Disasters; Routledge: London, UK, 2014.

28. Cutter, S.L. Vulnerability to environmental hazards. Prog. Hum. Geogr. 1996, 20, 529-539. [CrossRef]

29. Fuchs, S.; Birkmann, J.; Glade, T. Vulnerability assessment in natural hazard and risk analysis: Current approaches and future challenges. Nat. Hazards 2012, 64, 1969-1975. [CrossRef]

30. Dilley, M.; Boudreau, T.E. Coming to terms with vulnerability: A critique of the food security definition. Food Policy 2001, 26, 229-247. [CrossRef]

31. Yin, P.; Fang, X.; Yun, Y. Regional differences of vulnerability of food security in China. J. Geogr. Sci. 2009, 19, 532. [CrossRef]

32. Füssel, H.-M.; Klein, R.J. Climate change vulnerability assessments: An evolution of conceptual thinking. Clim. Chang. 2006, 75, 301-329. [CrossRef]

33. Yenneti, K.; Tripathi, S.; Wei, Y.D.; Chen, W.; Joshi, G. The truly disadvantaged? Assessing social vulnerability to climate change in urban India. Habitat Int. 2016, 56, 124-135. [CrossRef]

34. Lavell, A. Unpacking climate change adaptation and disaster risk management: Searching for the links and the differences: A conceptual and epistemological critique and proposal. IUCN-Flacso Proj. Clim. Chang. Adapt. Disaster Risk Reduct. 2011.

35. Kelly, P.M.; Adger, W.N. Theory and practice in assessing vulnerability to climate change and facilitating adaptation. Clim. Chang. 2000, 47, 325-352. [CrossRef]

36. Dong, Z.; Pan, Z.; An, P.; Wang, L.; Zhang, J.; He, D.; Han, H.; Pan, X. A novel method for quantitatively evaluating agricultural vulnerability to climate change. Ecol. Indic. 2015, 48, 49-54. [CrossRef]

37. Hulme, D.; Mosley, P. Finance for the Poor Or Poorest?: Financial Innovation, Poverty and Vulnerability; University of Reading, Department of Economics and Department of Agricultural Economics: Reading, UK, 1996.

38. Fischer, G.; Frohberg, K.; Parry, M.L.; Rosenzweig, C. Impacts of potential climate change on global and regional food production and vulnerability. In Climate Change and World Food Security; Springer: Berlin/Heidelberg, Germany, 1996; pp. 115-159.

39. Solomon, S.; Qin, D.; Manning, M.; Averyt, K.; Marquis, M. Climate Change 2007-the Physical Science Basis: Working Group I Contribution to the Fourth Assessment Report of the IPCC; Cambridge University Press: Cambridge, UK, 2007; Volume 4.

40. Mitter, H.; Kirchner, M.; Schmid, E.; Schönhart, M. The participation of agricultural stakeholders in assessing regional vulnerability of cropland to soil water erosion in Austria. Reg. Environ. Chang. 2014, 14, 385-400. [CrossRef]

41. Berry, P.; Rounsevell, M.; Harrison, P.; Audsley, E. Assessing the vulnerability of agricultural land use and species to climate change and the role of policy in facilitating adaptation. Environ. Sci. Policy 2006, 9, 189-204. [CrossRef]

42. Fellmann, T. The assessment of climate change-related vulnerability in the agricultural sector: Reviewing conceptual frameworks. Build. Resil. Adapt. Clim. Chang. Agric. Sect. 2012, 23, 37.

43. Wu, H.; Qian, H.; Chen, J.; Huo, C. Assessment of agricultural drought vulnerability in the Guanzhong Plain, China. Water Resour. Manag. 2017, 31, 1557-1574. [CrossRef]

44. Wilhelmi, O.V.; Wilhite, D.A. Assessing vulnerability to agricultural drought: A Nebraska case study. Nat. Hazards 2002, 25, 37-58. [CrossRef] 
45. Neset, T.-S.; Wiréhn, L.; Opach, T.; Glaas, E.; Linnér, B.-O. Evaluation of indicators for agricultural vulnerability to climate change: The case of Swedish agriculture. Ecol. Indic. 2019, 105, 571-580. [CrossRef]

46. Liang, L.; Ridoutt, B.G.; Wu, W.; Lal, R.; Wang, L.; Wang, Y.; Li, C.; Zhao, G. A multi-indicator assessment of peri-urban agricultural production in Beijing, China. Ecol. Indic. 2019, 97, 350-362. [CrossRef]

47. Li, Y.; Xiong, W.; Hu, W.; Berry, P.; Ju, H.; Lin, E.; Wang, W.; Li, K.; Pan, J. Integrated assessment of China's agricultural vulnerability to climate change: A multi-indicator approach. Clim. Chang. 2015, 128, 355-366. [CrossRef]

48. Pathiraja, E.; Griffith, G.; Farquharson, B.; Faggian, R. The Economic Cost of Climate Change and the Benefits from Investments in Adaptation Options for Sri Lankan Coconut Value Chains. In Proceedings of the International European Forum, Innsbruck-Igls, Austria, 13-17 February 2017; pp. 460-485.

49. Fischer, G.; Shah, M.M.; Van Velthuizen, H. Climate Change and Agricultural Vulnerability; IIASA: Laxenburg, Austria, 2002.

50. Wiréhn, L.; Danielsson, Å.; Neset, T.-S.S. Assessment of composite index methods for agricultural vulnerability to climate change. J. Environ. Manag. 2015, 156, 70-80. [CrossRef]

51. Teshome, M. Rural households' agricultural land vulnerability to climate change in Dembia woreda, Northwest Ethiopia. Environ. Syst. Res. 2016, 5, 14. [CrossRef]

52. Dwarakish, G.; Vinay, S.; Natesan, U.; Asano, T.; Kakinuma, T.; Venkataramana, K.; Pai, B.J.; Babita, M. Coastal vulnerability assessment of the future sea level rise in Udupi coastal zone of Karnataka state, west coast of India. Ocean Coast. Manag. 2009, 52, 467-478. [CrossRef]

53. Rani, N.S.; Satyanarayana, A.; Bhaskaran, P.K. Coastal vulnerability assessment studies over India: A review. Nat. Hazards 2015, 77, 405-428. [CrossRef]

54. Patnaik, U.; Narayanan, K. Vulnerability and Climate Change: An Analysis of the Eastern Coastal Districts of India; University Library of Munich: Munich, Germany, 2009.

55. Panda, A. Vulnerability to climate variability and drought among small and marginal farmers: A case study in Odisha, India. Clim. Dev. 2017, 9, 605-617. [CrossRef]

56. Islam, M.A.; Shitangsu, P.K.; Hassan, M.Z. Agricultural vulnerability in Bangladesh to climate change induced sea level rise and options for adaptation: A study of a coastal Upazila. J. Agric. Environ. Int. Dev. (Jaeid) 2015, 109, 19-39.

57. Kumar, A.A.; Kunte, P.D. Coastal vulnerability assessment for Chennai, east coast of India using geospatial techniques. Nat. Hazards 2012, 64, 853-872. [CrossRef]

58. Shukla, R.; Sachdeva, K.; Joshi, P. Inherent vulnerability of agricultural communities in Himalaya: A village-level hotspot analysis in the Uttarakhand state of India. Appl. Geogr. 2016, 74, 182-198. [CrossRef]

59. Smit, B.; Pilifosova, O.; Burton, I.; Challenger, B.; Huq, S.; Klein, R.; Yohe, G.; McCarthy, J.J.; Canziano, O.F. Adaptation and Vulnerability, Contribution of Working Group II to the Third Assessment Report of the Intergovernmental Panel on Climate Change: Adaptation to Climate Change in the Context of Sustainable Development and Equity; Cambridge University Press: Cambridge, UK, 2001; pp. 877-912.

60. Kantamaneni, K.; Phillips, M.; Thomas, T.; Jenkins, R. Assessing coastal vulnerability: Development of a combined physical and economic index. Ocean Coast. Manag. 2018, 158, 164-175. [CrossRef]

61. Kantamaneni, K.; Sudha Rani, N.; Rice, L.; Sur, K.; Thayaparan, M.; Kulatunga, U.; Rege, R.; Yenneti, K.; Campos, L.C. A systematic review of coastal vulnerability assessment studies along Andhra Pradesh, India: A critical evaluation of data gathering, risk levels and mitigation strategies. Water 2019, 11, 393. [CrossRef]

62. Krishna, V.K.R. Ground Water Brochure-Krishna District. Available online: http://cgwb.gov.in/District_ Profile/AP/Krishna.pdf (accessed on 20 October 2019).

63. Vijayawada Municipal Corporation. District Profile. Available online: https:/vijayawada.cdma.ap.gov.in/en/ district-profilehttps://vijayawada.cdma.ap.gov.in/en/district-profile (accessed on 8 July 2019).

64. Directorate of Census Operations. Village Town Directory. Available online: http://censusindia.gov.in/ 2011census/dchb/2816_PART_A_DCHB_KRISHNA.pdf (accessed on 22 October 2019).

65. Kumar, S.J. Groundwater Brochure, Guntur District-Andhra Pradesh. Available online: http://cgwb.gov.in/ district_profile/ap/guntur.pdf (accessed on 12 August 2019).

66. Rosegrant, M.W.; Ringler, C.; Zhu, T. Water for agriculture: Maintaining food security under growing scarcity. Annu. Rev. Environ. Resour. 2009, 34, 205-222. [CrossRef]

67. Atapattu, S.S.; Kodituwakku, D.C. Agriculture in South Asia and its implications on downstream health and sustainability: A review. Agric. Water Manag. 2009, 96, 361-373. [CrossRef] 
68. Dasgupta, S.; Hossain, M.M.; Huq, M.; Wheeler, D. Climate change and soil salinity: The case of coastal Bangladesh. Ambio 2015, 44, 815-826. [CrossRef] [PubMed]

69. Lamboll, R.; Stathers, T.; Morton, J. Climate change and agricultural systems. In Agricultural Systems; Elsevier: Amsterdam, The Netherlands, 2017; pp. 441-490.

70. Masutomi, Y.; Takahashi, K.; Harasawa, H.; Matsuoka, Y. Impact assessment of climate change on rice production in Asia in comprehensive consideration of process/parameter uncertainty in general circulation models. Agric. Ecosyst. Environ. 2009, 131, 281-291. [CrossRef]

71. Rao, K.N.; Subraelu, P.; Kumar, K.C.V.N.; Demudu, G.; Malini, B.H.; Ratheesh, R.; Rajawat, A. Climate change and sea-level rise: Impact on agriculture along Andhra Pradesh coast-A geomatics analysis. J. Indian Soc. Remote Sens. 2011, 39, 415-422.

72. Greeshma, R.; Bhave, M.; Kumar, P.S. Application of growth models for area, production and productivity trends of sugarcane crop for coastal Andhra region of Andhra Pradesh. Int. J. Agric. Sci. Res. 2017, 7, 7-14.

73. Malathi, M.; Rajakumari, S. Review of depleting coastal resource areas in GODAVARI delta upon human interventions, Andhra Pradesh. J. Coast. Conserv. 2019, 23, 543-551. [CrossRef]

74. Ray, K.; Arora, K.; Srivastav, A. Weather Extremes and Agriculture. In Proceedings of the International Archives of the Photogrammetry, Remote Sensing \& Spatial Information Sciences, Volume XLII-3/W6, ISPRS-GEOGLAM-ISRS Joint Int. Workshop on "Earth Observations for Agricultural Monitoring", New Delhi, India, 18-20 February 2019.

75. Das, H.P. Agrometeorological impact assessment of natural disasters and extreme events and agricultural strategies adopted in areas with high weather risks. In Natural Disasters and Extreme Events in Agriculture; Springer: Berlin/Heidelberg, Germany, 2005; pp. 93-118.

76. Sivakumar, M.V.; Motha, R.P.; Das, H.P. Natural Disaster and Extreme Events in Agriculture; Springer: Berlin/Heidelberg, Germany, 2005; Volume 376.

77. Riebau, A.R.; Fox, D.G. Damage assessment of agrometeorological relevance from natural disasters: Economic and social consequences. In Natural Disasters and Extreme Events in Agriculture; Springer: Berlin/Heidelberg, Germany, 2005; pp. 119-135.

78. Falco, S.D.; Adinolfi, F.; Bozzola, M.; Capitanio, F. Crop insurance as a strategy for adapting to climate change. J. Agric. Econ. 2014, 65, 485-504. [CrossRef]

79. Mcleman, R.; Smit, B. Vulnerability to climate change hazards and risks: Crop and flood insurance. Can. Geogr./Le Géographe Can. 2006, 50, 217-226. [CrossRef]

80. Naab, F.Z.; Dinye, R.D.; Kasanga, R.K. Urbanisation and its impact on agricultural lands in growing cities in developing countries: A case study of Tamale in Ghana. Mod. Soc. Sci. J. 2013, 2, 256-287.

81. PRS Legislative Research. State of Agriculture in India. Available online: https://prsindia.org/policy/ discussion-papers/state-agriculture-india (accessed on 5 June 2020). 